\title{
PEDRO I ANTE LOS ENFRENTAMIENTOS ENTRE CONCEJOS Y PRELADOS CASTELLANOS
}

\author{
ANA ARRANZ GUZMÁN \\ Universidad Complutense de Madrid
}

SUMARIO

1. Causas generadoras de litigios.- 2. Conflictos de larga duración, A. Palencia, B. Illescas, C. Sigüenza, D. Santiago de Compostela, E. Orense, F. Lugo.- 3. Conclusiones.

Hace algún tiempo llevamos a cabo un estudio sobre el reflejo que tuvieron en las Cortes castellanas los enfrentamientos entre concejos y poderes eclesiásticos desde el reinado de Fernando III hasta el de Enrique $I{ }^{\prime}$. Por él pudimos comprobar en qué circunstancias, por qué causas y en qué casos los procuradores de las ciudades denunciaban a los miembros del clero. Asimismo advertimos hasta qué punto el poder real trataba siempre de colocar bajo su control - muchas veces por invitación de alguno de los dos poderes enfrentados- el desarrollo de aquellos conflictos, sobre todo, cuando se trataba de un concejo de realengo, aunque también, por unos intereses más especiales, cuando el foco de lucha era un señorío episcopal.

El deseo de la monarquía de presentarse como una tercera fuerza mediadora con el propósito de alcanzar el mayor control sobre el medio urbano ha sido analizado con claridad para los reinados de Alfonso X,

\footnotetext{
'A. Arranz Guzmán, Los enfrentamientos entre concejos y poderes eclesiásticos en las Cortes castellanas: ¿sincronización de los conflictos?, "Hispania", 1989, pp. 5-68.

"Anuario de Estudios Medievales", 30/1 (2(K))
} 
Sancho IV, Fernando IV y Alfonso $\mathrm{XI}^{2}$. Ningún estudio conjunto, sin embargo, se ha realizado sobre el reinado de Pedro I. Sin duda, y al igual que en lo relativo a algunos otros temas, las causas que han desalentado a los investigadores han sido fundamentalmente dos: la mayor escasez de documentos, y la imposibilidad de observar la trayectoria de cada uno de los enfrentamientos a través de las protestas elevadas en Cortes, al contar tan solo con los cuadernos de peticiones de las de 1351 .

La pregunta que nos formulamos al iniciar este estudio es en qué medida Pedro I siguió la pauta marcada por sus inmediatos antecesores, o hasta qué punto la actitud que mantuvo ha de ser entendida como una postura especial y aislada respecto a la del conjunto de los monarcas castellanos. Para averiguarlo es preciso analizar tanto las causas más significativas que generaron la mayor parte de los conflictos, como cada uno de los enfrentamientos que tuvieron una larga trayectoria, en especial en los casos de señorío episcopal, y la intervención personal del monarca en ellos.

\section{CAUSAS generadoras DE Litigios}

Según se podrá ir comprobando, al igual que en tiempos anteriores, la mayor parte de enfrentamientos surgidos entre concejos y prelados durante el reinado de Pedro I estuvieron motivados también por razones de carácter económico y fiscal, y por asuntos jurisdiccionales: privilegios del clero en todos los órdenes, exenciones y excusados de las iglesias, injerencias en la justicia laica, abuso del arma de la excomunión, recaudación de diezmos, juicios a laicos.

Las denuncias de los ciudadanos elevados a los diferentes monarcas por la intromisión de los eclesiásticos en cuestiones temporales, sobre todo en las concernientes a la jurisdicción y economía concejiles, fueron, sin lugar a dudas, las más abundantes en la baja Edad Media; al menos así lo demuestran tanto el gran número de documentos particulares conservados, como la multitud de quejas y peticiones conjuntas formuladas al respecto por

'J.M. Nieto Soria, Iglesia y poder real en Castilla. El episcopado, 1250-1350, Madrid, 1988, pp. 167-191. 
los procuradores de las ciudades en Cortes ${ }^{3}$. En relación con la primera, es decir, con la jurisdicción, los ciudadanos subrayan una y otra vez que la injerencia de los prelados en ella conlleva, además del menoscabo general de la jurisdicción regia, una serie de graves consecuencias, tales como: el que se les permitiera juzgar en pleitos temporales; el apresamiento indebido de laicos; la utilización de las iglesias como refugios de delincuentes; el abuso del arma de la excomunión. En cuanto a los asuntos económicos y fiscales, los que más asiduamente se plantearon fueron: el exceso de excusados de algunas iglesias, que tanto perjudicaban a los concejos debido a que la percepción de impuestos se llevaba a cabo por el sistema de encabezamiento; los portazgos; los diezmos; el beneficiarse de los bienes comunales sin participar en las obras de la comunidad, etc.

La causa de los atropellos realizados por los eclesiásticos en materia jurídica no se debía a la falta de una legislación civil que lo contemplara, sino a la complejidad de ésta y, por supuesto, a la no siempre observancia de la misma. En las Partidas, Alfonso X ya había dedicado cuatro leyes a dicho tema: sobre las franquezas que poseían los clérigos para juzgar en pleitos temporales, en espirituales, y en aquellos relativos a los pecados ${ }^{4}$. No parece que existiera duda alguna en lo concerniente a cuestiones espirituales o de "pecado", pero sí sobre las temporales". No es necesario culpar al poder civil o al eclesiástico exclusivamente de una particular falta de escrupulosidad a la hora de delimitar sus respectivos ámbitos jurisdiccionales, ya que por ambas partes siempre hubo un deseo, más o menos velado, de ampliar sus atribuciones, provocando, a lo largo del Medievo faltas en los dos terrenos, lo que no quita que, por lo general, los ciudadanos acusaran al clero de ser el principal causante de una parte de los males que padecían ${ }^{6}$.

\footnotetext{
${ }^{3} \mathrm{Al}$ tema del eco que tuvieron tales denuncias en cortes dediqué un capítulo de mi tesis: Cortes medievales castellano-leonesas: participación eclesiástica y mentalidades religiosas, defendida en Alcalá de Henares en 1988, pp. 323-386. Y más recientemente en Clérigos y laicos en las Cortes castelano-leonesas: la conflictividad como hilo conductor, "El reino de León en la Alta Edad Media”, IX, León, 1997, pp. 637-717.

${ }^{4}$ I, leyes VI, LVI, LVII, LVIII y LIX.

sParece que no existió duda sobre los juicios de herejía, simonía, sacrilegio, adulterio, etc. Nadie negaba que todos aquellos que, en general, concernían a artículos de fe o a sacramentos fuesen materia exclusiva de los jueces eclesiásticos.

"El pensamiento que sobre el tema imperaba en los medios eclesiásticos se conoce perfectamente por la legislación conciliar. Los concilios, del mismo modo que las cortes, aunque desde una perspectiva bien distinta, también se ocuparon de las injerencias jurisdiccionales. Las teorías conciliares sobre la necesidad de demarcar el alcance de las competencias de ambas
} 
Cuando Pedro I accede al trono y celebra las Cortes de 1351 va a escuchar las mismas quejas contra el clero de los procuradores de las ciudades que habían oído ya los anteriores monarcas. No es difícil adivinar que las causas de esta herencia fueron, fundamentalmente, las siguientes: las escasas ocasiones en que los monarcas anteriores se habían decidido a afrontar con seriedad los problemas que conllevaba la falta de delimitación jurisdiccional; el abandono casi inmediato de cualquier proyecto reparador cuando éste, por fin, se había iniciado; la anteposición por parte de los soberanos de todo tipo de necesidades o problemas coyunturales; la propia legislación civil, según la cual un clérigo sólo podía perder sus privilegios si se demostraba su "cobdiçia"; la general desidia de los monarcas según puede apreciarse en las respuestas dadas ante las quejas y peticiones de los representantes de las ciudades en Cortes; y, por último, la falta de comunión existente entre la teoría y la práctica eclesiásticas al respecto.

Las primeras y únicas quejas y peticiones conjuntas conocidas elevadas por los ciudadanos a Pedro I son las de las Cortes de Valladolid de 1351. No obstante, y quizá por tratarse de la primera Asamblea que este monarca realizaba con los tres estados, los prelados hicieron también toda una relación de los agravios que sufría su estamento por parte de los otros dos. Sus quejas fueron las siguientes: no se respetaban sus privilegios; los clérigos eran demandados ante jueces seglares; los laicos "astragaban" sus abadengos; los oficiales reales atentaban contra su jurisdicción; los ricos hombres "en los lugares do ellos an vasallos lançan pechos a los sus vasallos et les toman yantares en vianda, et por esto que se les yerman"?

Respecto a las peticiones formuladas por los procuradores de las ciudades, además de las que atendían a asuntos concretos como los acaecidos en Galicia que más adelante analizaremos, fueron las mismas que oyó su

jurisdicciones comulgaban plenamente con las ideas presentadas en cortes. Pero en los concilios, como era de esperar, a la hora de señalar quien era el agresor y quien la víctima, chocaban de lleno con el parecer de los laicos. Claro ejemplo de ello son dos cánones de los concilios de Valladolid de 1322 y de Salamanca de 1335. En el primero de ellos, por ejemplo, y a pesar de señalar en primer lugar que las jurisdicciones eclesiástica y seglar deben ayudarse una a otra, inmediatamente después se acusa a algunos jueces laicos porque "despreciando los estatutos de los cánones publicados sobre esto, obligan contra derecho a los clérigos y a otras personas eclesiásticas a litigar en su tribunal sobre sus cosas y causas generales". Para poner fin a esta intromisión se ordena la publicación en sínodos e iglesias del estatuto de Bonifacio VIII "Quoniam ut intelleximus", a la vez que se amenaza a los predichos jeces con la excomunión. Vid. además J. Tejada y RAmiro, Colección de cánones y de todos los concilios de la Iglesia española, Madrid, 1851, Concilio de Salamanca de 1335, c. VIII, p. 573.

${ }^{7}$ Cortes de los antiguos reinos de León y de Castilla, Madrid, 1861-1866, II, pp. 125-129. 
padre en las Cortes celebradas durante su reinado, en concreto, en las de $1315,1322,1325$, o $1348^{8}$. En esta última asamblea, los ciudadanos habían presentado como una de las causas principales provocadoras de litigios jurisdiccionales el hecho de que cada vez que alguna autoridad laica llamaba la atención a un eclesiástico por haber extendido su jurisdicción allá donde no le concernía, en seguida mostraba un privilegio concedido por alguno de los sucesivos monarcas. Lo que provocaba, según palabras de los propios procuradores, el menoscabo de la jurisdicción y justicias regias. Pedro I tuvo que oír una queja similar en este sentido, demostrándose con ello que la situación no había variado:

\footnotetext{
A lo que me pidieron por merçed que non consienta que ningun rico omme nin perlado nin otro poderoso faga enbargo en los alfozes e aldeas de las mis çibdades e villas tomando yantares nin usando de la juridiçion e justiçia que pertenesçe a mi e a las justiçias que por mi estan en las dichas çibdades e villas nin ayan y comiendas nin vasallos, que dizen que los non deven aver, nin sean apoderados tales perlados de las fortalezas de las mis çibdades e villas nin de las puertas dellas".
}

La respuesta de Pedro I fue tajante: los prelados no podrían "usar de la justiçia e juridiçion que a mi pertenesçe”, ni tener las llaves de las ciudades y villas de realengo, debiéndoselas entregar a los vecinos elegidos por el concejo o a los oficiales reales.

El disfrute indebido de los bienes comunales, así como el deterioro de los mismos por causa de pastar sin vigilancia los ganados pertenecientes a los prelados fueron también temas de protesta en las cortes vallisoletanas ${ }^{10}$. El potenciador de dichas quejas hay que buscarlo en la existencia de excusados. En unos "excusados", "paniaguados", o "familiares" de clérigos a los que el estamento eclesiástico hacía extensivos sus privilegios de exención de impuestos y servicios, lo que conllevaba que las obligaciones tributarias recayeran exclusivamente sobre la capa de población libre no sometida a poderes señoriales: los pecheros.

La protesta de los representantes de las ciudades en torno al tema de los excusados no era la primera vez que se hacía a un monarca, ni iba a ser

\footnotetext{
${ }^{8}$ Cortes, I, pp. 365, 382, 386, 540, 630 y 631.

${ }^{9}$ Cortes, II, p. 57.

${ }^{10}$ Cortes. II, pp. 58-59 y 68.
} 
la última; tampoco habían variado, ni variarían los motivos que les empujaban a la misma: los excusados no contribuyen en aquellos servicios y "pechos" a que están obligados por motivos comunales o de vecindad; cada día se aumenta más el número de "paniaguados" con el consiguiente perjuicio económico para los pecheros; la jurisdicción regia se daña constantemente, ya que dichos "excusados" se sienten con pleno derecho para menospreciar a los jueces civiles, alegando que ellos tan solo pueden ser juzgados por un tribunal eclesiástico; no obstante a no pagar con los concejos de aquellos lugares donde moran, utilizan sus aguas, sus pastos, talan sus montes, etc ${ }^{11}$. La respuesta de Pedro I ante esta relación de agravios fue idéntica a la dada por sus antecesores. Una respuesta, que si bien es cierto que obligaba a contribuir a quienes se beneficiaban de los bienes comunales en los pechos concejiles, no zanjaba realmente el problema, como lo demuestran las confirmaciones de privilegios al clero emitidos por el monarca al respecto en esos mismos años y con posterioridad, y los conflictos locales que se declararían a lo largo de su reinado por el mismo tema, y que volverían a salir a la luz en las Cortes burgalesas de 1373 celebradas por Enrique II' ${ }^{12}$.

Otro de los asuntos que llevaron a los ciudadanos a quejarse ante Pedro I y requerir su intervención fue el relativo al apresamiento indebido de laicos por parte de miembros del clero, así como la excesiva y arbitraria utilización de su más poderosa arma, la excomunión. De acuerdo con la documentación conocida, consideramos que las causas esenciales por las que los eclesiásticos encarcelaban a personas ajenas a su jurisdicción pueden resumirse en las siguientes: las luchas personales entabladas entre personajes de los dos estamentos privilegiados, cuyas consecuencias eran padecidas por los pecheros; los enfrentamientos abiertos y de larga duración entre concejos y eclesiásticos, que más adelante analizaremos; las deudas, o posibles deudas, contraídas por algunos vecinos con la Iglesia; problemas de carácter económico-fiscal y jurisdiccionales en general.

La excomunión aparece en todas las fuentes eclesiásticas tanto jurídicas como literarias, como la principal arma esgrimida por la autoridad clerical. Un arma temida por sus graves consecuencias, pero al mismo tiempo denunciada, como lo demuestra la cantidad de documentación

\footnotetext{
"Cortes, II, pp. 58 y 126.

'Cortes. II. pp. 263-264.
} 
bajomedieval que sobre ello se conserva. En teoría, su finalidad no era la de castigar, sino la de sanar el "alma pecadora" y así se nos muestra tanto en los cánones conciliares como en algunos escritos de figuras eclesiásticas relevantes. Tal es el caso, por ejemplo, del "Libro de las consolaciones de la vida humana" del Papa Luna ${ }^{13}$. Por su parte, los concilios intentaron ofrecer, a lo largo de todo el Medievo, una imagen positiva de la excomunión, aunque, eso sí, calificando siempre de "hijos de Belcebú" a quienes impedían la administración de la misma, y amenazando con la muerte conjunta del alma y el cuerpo a aquellos que no la respetasen ${ }^{14}$.

La legislación civil también se ocupó de forma exhaustiva de la excomunión. En concreto, Alfonso $\mathrm{X}$ trató de ella ampliamente en las Partidas, partiendo de una división previa entre lo que se denominaba "excomunión mayor" y "excomunión menor". Pero lo que más interesaba subrayar al Rey Sabio es que los eclesiásticos, para obrar rectamente en relación con la pena de excomunión, debían, en primer lugar, amonestar al sujeto previamente, y, en segundo, llevarla a cabo tan solo por causa justificada y no por mala voluntad o intereses personales ${ }^{15}$.

Por último, cabe mencionar que este tema fue tratado igualmente, y desde diferentes puntos de vista, por autores tan prestigiosos como Alvaro Pelayo y Marsilio de Padua. Para el primero, según aparece en su "Collyrium adversus hereses", todo aquel que pretenda que la Iglesia no ha recibido del mismo Cristo el derecho de excomulgar, sino que se lo arroga para inspirar miedo o por espíritu de lucro, es un hereje. Para Marsilio de Padua, por el contrario, ningún eclesiástico puede excomulgar a nadie sin la determinación de un concilio general o del monarca ${ }^{16}$.

\footnotetext{
${ }^{13}$ BAE, Madrid, 1952, p. 592. En él, el Papa Luna se remite a la idea de San Juan Crisóstomo sobre los orígenes de la excomunión. Vid. J.J. BERNIIARD, Exconmunication et penitence-sacrament aux deux prémiers síécles de l'Eglise. Contribution canonique, "Revue de Droit Canonique", 1965-1966; у C. VoGEL, Penitencia y excommión en la Iglesia antigua y alta Edad Media, "Concilium", 107 (1975), pp. 9-21.

${ }^{14}$ Un ejemplo de la línea conciliar la tenemos en el canon dedicado a la excomunión en el concilio de Salamanca de 1335, en el que se dice: "Empleándose la saeta de la excomunión medicinal para sanar las heridas de los enfermos y curándose la llaga en los pecados con la persecución piadosa para que, después de obtenidos los remedios de la salud se admitan dentro del regazo de la piedad material aquellos que por sus culpas habian sido alejados de el", TEJADA Y RAMIRO, Colección, p. 578.

${ }^{15}$ Partidas, I, IX, I, II, XX.

${ }^{1 "} \mathrm{~N}$. IUNG, Un franciscain théologien du pouvoir pontifical au XIVe siècle: Alvaro Pelayo, eveque et pénitencier de Jean XXII, París, p. 129. M. DE PADUA, Defensor Pacis, parte II, cap. XXI.
} 
La actitud por parte de la sociedad laica ante la excomunión con la que se encuentra al subir al trono Pedro I es idéntica a la que hallaron sus antecesores: los ciudadanos, lejos de preocuparse por las consecuencias espirituales que podía implicar el hecho de estar excomulgado, iban a centrar sus quejas, al igual que hasta entonces, en dos aspectos. En primer lugar, en el proceder injusto y arbitrario de los eclesiásticos, y en segundo en la intromisión en la jurisdicción real al emplear el arma de la excomunión "por las cosas temporales". Algunas de las soluciones que ofrecían ante tales abusos, y que de modo global se habían ido repitiendo por los procuradores en Cortes, incluidos los de 1351, eran las siguientes: prohibir a los clérigos excomulgar por cuestiones correspondientes a la jurisdicción civil; que si los eclesiásticos hicieran caso omiso a tal recomendación, los oficiales reales y el resto de los ciudadanos no favoreciesen su injusto cumplimiento; que si los miembros del clero recibiesen algún agravio de los laicos se lo hiciesen saber al rey antes de proceder a excomulgarlos para que el monarca pudiera poner solución al conflicto; que si el rey viese injusta alguna de las excomuniones llevadas a cabo, pida al eclesiástico que "alçe la sentençia", y que si así no lo hiciese que le "mandasse peyndrar e tomar lo que le fallasse ffasta que la alçassen"; que en caso de haber actuado según derecho, el excomulgado no pene más del tiempo que se le exigió ${ }^{17}$.

Dejando a un lado estas primeras protestas de carácter general formuladas en Cortes y que, sin duda, era el fruto que Pedro I recibía de la situación padecida por los concejos de algunas ciudades durante los reinados anteriores, parece preciso tratar de reconstruir la trayectoria que siguieron a lo largo del de Pedro I para averiguar si los conflictos que se originaron en el mismo, sus causas, y los lugares geográficos antes afectados, fueron idénticos respecto a los de años pasados, o si, por el contrario, sufrieron variaciones considerables tras su subida al trono.

Después de un minucioso análisis, hemos comprobado que los prelados que mayor conflictividad vivieron con los vecinos de las ciudades donde eran titulares o con los de algunos pertenecientes a su señorío episcopal entre 1350 y 1369 fueron los arzobispos de Toledo y de Santiago, los obispos de Lugo, Mondoñedo, León, Oviedo, Segovia, Palencia, Cartagena, Coria, Orense, Córdoba y Sigüenza. Buena parte de ellos

\footnotetext{
${ }^{17}$ Estos puntos se trataron en las cortes de León de 1208, de Burgos de 1301, de Zamora de 1301, de Valladolid de 1307, de Alcalá de 1348, y de Valladolid de 1351, Cortes, I, pp. 50. $144,154,155,193-194,426 ;$ y II, p. 22.
} 
protagonizaron enfrentamientos de larga duración; es decir, que provenían de reinados anteriores y que, tras la muerte de Pedro I, se mantendrían vigentes hasta muchos años después. Dado el interés de estos conflictos centenarios hemos considerado oportuno dedicarles un apartado concreto, aunque sin olvidar las causas generadoras de aquellos otros de menor entidad y que, en parte, quedaron reflejados, ya según vimos, en las Cortes de 1351.

La mayor parte de las confirmaciones de privilegios o exenciones del clero llevadas a cabo por Pedro I fueron emitidas a lo largo de la celebración de las Cortes vallisoletanas ${ }^{18}$. Ante ello, y como hasta entonces había ocurrido cada vez que accedía al trono un nuevo rey, nada podían hacer los ciudadanos. Pero también, al igual que siempre, desde los primeros meses del reinado, los representantes de los concejos no dejarían de quejarse ante los abusos de poder perpetrados por el clero y, en particular, por los prelados, con el deseo de una inmediata intervención regia dirimitoria.

Uno de los asuntos más frecuentemente llevados ante el monarca fue el de los excusados. En unas ocasiones Pedro I podía partir, sin mayores problemas, de privilegios anteriores que ya habían zanjado el conflicto. Así, por ejemplo, el 15 de octubre de 1351 , el rey confirmó una carta de avenencia de Alfonso XI entre el obispo de Avila y el concejo de la ciudad en razón de la cual los excusados de pechos no podían ser más que cuarenta mozos de coro $^{19}$. En otras ocasiones, ante la duda de Pedro I y las protestas de un obispo por no mantener las exenciones de sus excusados, se iniciaba una pesquisa que, por lo general, acababa beneficiando al clero. Tal fue el caso de la abierta ante la presión de la Iglesia ovetense y que se cerraría en 1355 con la resolución de Pedro I donde se notificaba al juez de esta ciudad y a otros oficiales que debían respetarse los quince excusados del obispo, los seis del deán, y los cuatro de cada dignidad, que se hallaban exentos de moneda y servicio desde tiempos de Alfonso X.

Los enfrentamientos entre concejos e iglesias por intentar los primeros que los clérigos pagasen determinados pechos a la ciudad en algún momento, se llevaron con frecuencia asimismo ante Pedro I para que los diera solución; e igualmente casi siempre, eran los eclesiásticos quienes salían beneficiados. Valgan como ejemplo la provisión real fechada el 29 de 1975.

${ }^{18}$ Ver L.V. Díaz Martín, Itinerario de Pedro I de Castilla. Estudio y regesta, Valladolid,

${ }^{19} \mathrm{AHN}$, Clero, carp. 29, no 17. 
marzo de 1354 ordenando al concejo sevillano que no impusieran pechos a los clérigos de dicha ciudad; o la carta que en este mismo año envió al concejo de Santiago ordenando que no cobraran al cabildo de la ciudad el impuesto de vino según se hacía en virtud de una ordenanza concejil ${ }^{20}$. Aunque no siempre fue así, en especial cuando se trataba de que los clérigos y familiares contribuyeran en las obras de bien comunal; así, en 1365 Pedro I, ante la queja del concejo murciano, ordenaría que los clérigos, sus mancebas e hijos pagaran lo que les correspondiera en la labor de la cerca, puentes, escuchas, atalayas y guardas puestos para defensa de la ciudad, so pena de pagar seiscientos maravedíes de multa.

También dentro de las cuestiones de orden fiscal, los litigios por portazgos ocuparon un lugar destacado, llegando a ser una de las causas más habituales ante las que el monarca debía tomar postura. Los enfrentamientos por este impuesto estuvieron originados por tres razones: porque los vecinos se negaran a pagar portazgo a una determinada iglesia; porque algún concejo obligara a pagarlo a los vasallos de determinado prelado; o porque algún concejo, pese a las exenciones reales que disfrutaban sus eclesiásticos, hicieran caso omiso de las mismas. En cada uno de estos tipos de conflicto se solicitó la intervención regia. Un ejemplo del primero de ellos fue la negativa de los vecinos de Perera a pagar a la Iglesia ovetense el portazgo de Olloniego, alegando para ello el ser vecinos de Oviedo. La actitud de Pedro I fue clara, según consta en la provisión de 1361 por la que ordenaba a los vecinos el pago de dicho portazgo, además de condenarles a las costas por el recurso de alzada que habían presentado ${ }^{21}$. Ejemplo del segundo es la provisión de la Real Audiencia con fecha 6 de diciembre de 1351 y en nombre de Pedro I, por la cual, ante la querella presentada por el obispo de Segovia, se ordena al concejo, alcaldes, y alguacil de Sepúlveda y a los recaudadores del portazgo de dicho lugar que no cobren a los vecinos y moradores de Riaza, vasallos del obispo, por las mercaderías que llevasen a Sepúlveda o pasasen por ella o su término, ya que según una pesquisa

\footnotetext{
${ }^{20}$ A.C. Sevilla, caj. 38, carp. 2, fol. 39. López Ferrejro, Historia de la Santa $A . M$. Iglesia de Samtiago de Compostela, Santiago, 1898-1909. VI, p. 153; y Fueros municipales de Samtiago y' su tierra, Santiago, 1895-1896. II, p. 67. A.L. Molina Molina, Documentos de Pedro I, CODOM, Murcia, 1978, doc. 134.

"A.C. Oviedo, carp. 21, n" 9. Not. García Larragueta, Catálogo de pergaminos de la catedral de Oviedo, doc. 776, p. 265.
} 
realizada durante el reinado de Alfonso XI estaban exentos de pagarlo ${ }^{22}$. Del último tipo de litigio existe un claro exponente en el especialmente conflictivo concejo de Burgos. Las querellas entre los sucesivos obispos, el cabildo y el concejo burgalés por la cuestión de los portazgos habían sido constantes desde el reinado de Alfonso XI. La causa por la que el concejo no aceptaba las exenciones sobre portazgos que la Iglesia disfrutaba no era otra, según ya han apuntado algunos historiadores, que "la rivalidad económica y administrativa de las instituciones burgalesas implicadas" ${ }^{23}$. En cualquier caso, la continuidad del enfrentamiento en el reinado de Pedro I queda probada por las dos cartas de privilegio que el monarca tuvo que mandar en menos de tres años confirmando al obispo e Iglesia de Burgos, así como a sus vasallos, el privilegio que disfrutaban de exención de portazgo ${ }^{24}$.

El cobro de los diezmos fue, asimismo, uno de los motivos generadores de enfrentamientos, y al igual que en relación con los portazgos, casi siempre se hallaban enmarcados en una situación de conflictividad general. En todos los casos conocidos se hizo precisa la intervención del rey, aunque, a diferencia de otras resoluciones sobre distintos problemas, Pedro I no siempre favorecería al estamento eclesiástico. Sin duda, esta actitud regia, como veremos para el caso murciano, estuvo ocasionada por las malas relaciones mantenidas entre el monarca y el obispo de Cartagena tras el apoyo de éste al bando trastamarista. Así, mientras, que en 1354 Pedro I ante la queja del concejo murciano se había limitado a mandar al obispo don Alfonso de Vargas que no demandase a la ciudad y su término el diezmo de las ovejas paridas ni de los becerros por no ser uso y costumbre ${ }^{25}$, en 1368 el monarca no dudaría en mandar un escrito al concejo de Murcia para que informaran a los eclesiásticos sobre que no debían observar la censura y

"2A. García larragueta, Colección diplomática de Riaza (1258-1457), Segovia, 1959. doc. 15, pp. 26-29.

${ }^{23}$ Ver sobre este asunto T. RuIz, Sociedad y poder real en Castilla, pp. 101-102; y NiETo SORIA, Iglesia y poder real, p. 171.

${ }^{24}$ La primera data del 25 de octubre de 1351 y la segunda del 19 de abril de 1354, A.C. Burgos, v. 2, p. 2, fols. 40 y 42 .

${ }_{25}^{25}$.M. Murcia, Cartas Reales, Eras 1386-1392, fol. 87. Not. en BN, Ms. 13.075, fol. 208 v. CODOM, doc. 70 . 
entredicho puestos por el obispo don Nicolás de Aguilar a causa de estar enfrentado al rey; y que si así no lo hicieran, no les pagaran los diezmos ${ }^{26}$.

Durante el largo pontificado del obispo de Mondoñedo don Alfonso Sánchez (1347-1366), si bien es cierto que no hemos hallado noticias sobre conflictos surgidos entre el prelado y la ciudad de Mondoñedo por el señorío que los prelados ejercían sobre ella desde el año 1117, sí hemos encontrado documentación acerca de los acaecidos con los vecinos de la villa de Vivero, también bajo su señorío, y que en los años 1173, 1223, 1254, 1287, 1293, y 1346 ya habían protagonizado rebeliones al negarse a aceptar al obispo como su señor jurisdiccional ${ }^{27}$. En 1352 Pedro I ya se había ocupado de confirmar a la Iglesia de Mondoñedo sus privilegios, así como de ordenar al adelantado mayor de Galicia y a los merinos respetar los derechos de los moradores sujetos a la Iglesia mindunense ${ }^{28}$. Sin embargo, según había podido comprobar ya el monarca en las Cortes de 1351, los enfrentamientos entre el obispo, los oficiales reales, y los vecinos de Vivero por los diezmos seguían vigentes a pesar de la intervención que los reyes, desde Alfonso IX hasta su padre, habían llevado a cabo $^{29}$. Los problemas entre el obispo y Vivero no se acabaron en el tema de los diezmos, ya que, en plena guerra civil, temiendo el concejo que la villa fuese atacada por los partidarios de Enrique de Trastámara desde el convento de Santo Domingo, los vecinos derribaron el claustro y el cementerio monásticos, pactando no obstante una concordia con el prior de los dominicos, fray García de Ortigueira, por la que se obligaban a pagar doce mil maravedíes en el plazo de tres años para reparar los daños ocasionados al monasterio. Ante la destrucción del convento, don Alfonso Sánchez les había excomulgado, aunque tras dicha concordia de 1356 levantó la pena ${ }^{30}$.

\footnotetext{
${ }^{26} \mathrm{BN}$, Ms. 13.075, fol. 210 v; y RAH, Col. Morales, XII, fol. 124.

${ }^{27} \mathrm{BN}$, Ms. 5.928, fols. 63 r y 69 v. Cit. NIETO SORIA, Iglesia y poder real, p. 186; y A. Rodríguez González, Pedro I de Castilla y Galicia, "Boletín de la Universidad Compostelana", 64 (1956).

${ }^{28}$ Díaz MARTín, Itinerario, docs. 483 y 484, p. 283.

${ }^{29}$ Cortes, II, p. 73. La queja de la ciudad de Vivero ante la presión de los oficiales reales para cobrar el diezmo, ya que asimismo se la debían pagar al obispo de Mondoñedo, hace pensar sobre si la mayoría, de una forma más o menos velada, se aprovechaba de la conflictividad concejos-prelados para solicitar unos impuestos que no le correspondían.

${ }^{30}$ Pardo Villar, El convento de Santo Domingo de Vivero, "Boletín de la Comisión Provincial de Monumentos Históricos y Artísticos de Lugo", II (1945-1947), pp. 177-178.
} 
El último ejemplo de intervención real relacionada con los diezmos que presentamos tiene un valor especial por ser los arrendadores de los mismos sus principales protagonistas. El conflicto, acaecido esta vez en Córdoba, nació por el procedimiento usual utilizado por la Iglesia cordobesa para percibir los diezmos: el arrendamiento ${ }^{31}$. La causa del mismo fueron los subterfugios empleados por los arrendadores para evitar cualquier responsabilidad por las posibles deudas contraídas a causa de los contratos de arrendamiento. La argucia más comúnmente empleada por ellos era la de dar por fiadoras a sus propias esposas, cuyos bienes, por ley de Alfonso XI, no podían ser embargados ${ }^{32}$. Esta disposición tuvo tales consecuencias que Pedro I, en 1350 primero y en 1352 después, ante las demandas del obispo don Martín Jiménez y del resto de la clerecía cordobesa, tuvo que mandar a las autoridades de la ciudad que hicieran cumplir los contratos firmados a los arrendadores de los diezmos, y que no tuvieran en cuenta la voz de sus esposas a no ser que éstas hubieran denunciado tales contratos en el momento que fueron suscritos por sus maridos ${ }^{33}$. No obstante, a pesar de la intervención regia, y como en tantos otros asuntos, los conflictos por los arrendamientos del diezmo no terminarían con ello, según lo demuestra el hecho de que Enrique II se viera obligado también a hacer de árbitro tras su acceso al trono.

Aunque ya no nos remitamos a otros conflictos concretos sobre diezmos, consideramos de interés mencionar también que el asunto de los denominados diezmos personales ${ }^{34}$ había venido originando un malestar tan grande en tiempos anteriores que los procuradores de las ciudades no dudarían en abordarlo en las Cortes celebradas por Pedro I en 1351:

\footnotetext{
${ }^{31}$ El tema de los arrendadores de diezmos para el caso cordobés ha sido estudiado por I. Sanz Sancio, La Iglesia de Córdoba en la baja Edad Media, UCM, 1988, p. 474.

${ }^{32} \mathrm{La}$ argucia se respaldaba en el punto diecisiete del ordenamiento de las cortes leonesas celebradas por Alfonso XI, según creemos, en 1345, y no en 1349, fecha con la que fueron publicadas por la Real Academia de la Historia: "A lo que nos pedieron por merced que por fiaduria quel marido faga en qualquier manera o por qualquier rrazon, que la muger nin sus bienes non sean tenudos a ella", Cortes, I, p. 632.

${ }^{33}$ A.C. Córdoba, caj. P, no 219 y 220.

${ }^{34}$ Sobre la obligatoriedad de estos diezmos queda un ejemplo, entre otros, en los sinodales giennenses, como ya trató RODRÍGUEZ MOLINA en El diezmo eclesiástico en el obispado de Baeza-Jaén, "Hispania", 1977, p. 219. Ver también el estudio de M.L. Guadalupe BERAZA, Diezmos de la sede toledana en el siglo XV. p. 15.
} 
A lo que dizen que en algunas çibdades e villas e lugares de mis rregnos han de huso e de costunbre de non pagar diezmos personales, e que muchos clerigos que demandan nuevamiente los dichos diezmos de todas las cosas que por menudo conpran e venden e arrendan e ganan por sus menesteres, non seyendo tenudos a lo pagar por lo que dicho es, e pagando conplidamente los diezmos prediales de pan e de vino e de los otros frutos e de los ganados que han, et que muy sueltamiente que pasan contra ellos a penna de descomunion porque non pagan los dichos diezmos personales; e que porque a mi pertenesçe alçar las fuerças e los agravios de tales fechos asi commo braço seglar, pedieronme merçed que rrogase e mandase a los prellados que manden guardar esto porque se pase segunt la costumbre de los logares e tierras do acaesçieren e que defiendan a los clerigos de sus obispados que los non demanden de aqui adelante los dichos diezmos personales do non an huso nin costunbre de los pagar, et los vicarios que los julguen asi; et que en los lugares do lo an asi de uso e de costunbre, que paguen segunt la costunbre que han commo dicho es e non mas ${ }^{35}$.

La respuesta de Pedro I fue breve, así como favorable a que se atendiese y respetase la petición de los procuradores de las ciudades. Pero todo se quedó ahí.

Hasta el reinado de Alfonso XI los monarcas, sobre todo desde Alfonso X, habían mantenido una actitud muy concreta respecta al diezmo: por un lado, se preocuparon de promulgar leyes sobre los tipos de diezmos existentes y la manera en que se debía diezmar ${ }^{36}$; por otro, los sucesivos reyes, a través de sus oficiales, intervinieron siempre que fue necesario por la impotencia y solicitud de la Iglesia en su recaudación. Aunque no es este el momento de hablar sobre el interés de la monarquía castellana por la percepción del diezmo ${ }^{37}$, sí es necesario mencionar que, a pesar de las normativas dadas por los reyes, en donde se recogen las directrices fundamentales para facilitar la labor de los recaudadores del diezmo, la percepción del mismo nunca se vio libre de conflictos ${ }^{38}$. Así, según se puede observar por el texto de las Cortes vallisoletanas, los litigios entre clérigos y laicos por la recaudación de algún tipo de diezmo no habían

\footnotetext{
${ }^{35}$ Cortes, II, pp. 13-14.

${ }^{36}$ La más extensa normativa civil sobre el diezmo fue la elaborada por Alfonso X en el título $\mathrm{XX}$ de la I Partida.

${ }^{37} \mathrm{~A}$ este tema dediqué un capítulo de mi Tesis titulado "El interés de los monarcas por la percepción del diezmo; las tercias", I, pp. 415-430.

${ }^{38}$ Ver sobre el tema, ARRAnz GUZMÁn. Clérigos y laicos, pp. 689-695.
} 
cesado durante el reinado de Alfonso XI. La petición hecha por los procuradores no puede ser más elocuente. Nadie se niega en principio a pagar el diezmo que afectaba a los productos agropecuarios, es decir, de las rentas producidas en el sector primario de la economía. El conflicto, pues, radica en que a pesar de existir toda una normativa civil y eclesiástica que obligaba a todo cristiano a entregar el diezmo de cualquier beneficio económico obtenido al margen de los prediales, no parece que se aceptara resignadamente diezmar por las rentas procedentes de la artesanía o comercio, según queda demostrado en el texto citado, en el que los procuradores, basándose en la tradición de que algunas ciudades tenían de uso y costumbre no pagar diezmos personales, solicitan la intervención del rey para que los eclesiásticos dejen de exigir tales diezmos y de lanzar la excomunión contra quienes se negaban a hacerlos efectivos.

Probablemente, y a pesar de la respuesta favorable de Pedro I, la falta de cobertura legal, en última instancia, debió ser la causa de que no se produjeran posteriores denuncias sobre este asunto en un número significativo por parte de los ciudadanos. No obstante, sabemos que la conflictividad a causa de los diezmos personales continuó existiendo, más o menos de forma latente, hasta el reinado de Juan $\mathrm{II}^{39}$.

Otro de los asuntos provocadores de fricciones constantes fue el de los "falsos clérigos", es decir, el de los hombres que se llamaban clérigos sin serlo al no tener órdenes sagradas, así como el de sus esposas y paniaguados. La primera queja general formulada se hizo también en las Cortes de 1351. En ellas los procuradores de las ciudades se quejaron de que dichos clérigos falsos cometen todo tipo de tropelías, y de que cuando por algunos de sus maleficios perpetrados los jueces y alcaldes de las ciudades les prenden, los prelados y jueces eclesiásticos excomulgan a los representantes de la ley civil, dañándose seriamente con ello la jurisdicción real. La respuesta de Pedro I fue clara: pedir a los prelados que no les defiendan, y ordenar a sus justicias seguir actuando con ellos según corresponde, es decir, como con cualquier otro laico ${ }^{41}$. Sin embargo, tampoco en este asunto la resolución de Pedro I tuvo efecto, tal y como lo demuestran las

\footnotetext{
${ }^{34}$ Cortes, III, p. 351 . En el caso concreto del obispado de Córdoba se sabe que el contlicto por los diezmos personales que enfrentó a la Iglesia y a los concejos cordobeses durante mucho tiempo, no concluyó hasta que Juan II emitió en 1449 un dictamen definitivo, Sanz Sancilo. La Iglesia de Córdoba. pp. 979-980.

"'Cortes, II, p. 21.
} 
quejas particulares elevadas por distintos concejos en fechas posteriores, ante lo cual Pedro I sólo podía remitirse a lo ya dispuesto en $1351^{41}$.

Aunque en buena parte de los asuntos ya mencionados, generadores de enfrentamiento, se ha podido ir observando hasta qué punto los prelados lanzaban la excomunión siempre que lo consideraban conveniente, parece oportuno, para concluir este apartado, completar algo más la información que sobre este arma eclesiástica nos ofrecen los documentos de este reinado. Como en el resto de los temas tratados, una de las cuestiones que más nos interesa es saber cual fue la actitud de Pedro I ante la utilización de la excomunión por parte de los prelados de su reino. Desde luego, es de suponer que el monarca mirara con cierto recelo la utilización de este arma, en cuanto que él mismo la había sufrido por parte del pontificado. Pero no hace falta recordar que no fue el único rey castellano a quien un papa había excomulgado, por lo que su actitud tampoco resulta especialmente distinta respecto a la de sus antecesores en el trono.

Las intervenciones de Pedro I en materia de excomunión y entredicho pueden dividirse, de acuerdo con el carácter de las mismas, en cuatro apartados, según correspondiera a querellas presentadas por los concejos; a la utilización de la excomunión contra los oficiales reales; por la excomunión de algún eclesiástico perteneciente a su patronato; o con el propósito de que no se tuviera en cuenta la excomunión lanzada por algún obispo enfrentado a él.

Sobre protestas elevadas por algunos concejos y oficiales a causa de haber caído en entredicho o excomunión queda bastante documentación. En las páginas precedentes ya hemos mencionado algunos ejemplos de ello; no obstante dada su especial significación resulta de especial interés mencionar alguno más. El primero de ellos se refiere al concejo y obispo leoneses. León era uno de los lugares que arrastraba una continua conflictividad desde mucho tiempo atrás, debido, sin duda, a que si por un lado era una ciudad de realengo siendo su concejo un señorío jurisdiccional vinculado directamente al poder real, por otro, el obispo y el cabildo ostentaban también otro

\footnotetext{
${ }^{41}$ Valga como ejemplo la provisión de Pedro I de 1354, enviada a don Alfonso, obispo de Cartagena, ante la queja presentada por el concejo murciano. En ella, ordena al obispo, vicarios y jueces de la Iglesia de Cartagena que se atengan a lo dispuesto en las cortes de Valladolid sobre quien debe juzgar a los que se dicen clérigos sin serlo, Molina Molina, Docimentos de Pedro I, doc. 81, pp. 144-145.
} 
gran señorío jurisdiccional sobre parte de la ciudad y de su alfoz ${ }^{42}$. La lucha, pues, entre concejo y prelados era inevitable. El propósito de una y otra parte no era otro que el de limitar el poder de su adversario y engrandecer el suyo propio.

La actitud de Pedro I ante este conflicto está lleno de matizaciones. Desde un principio el rey concedió muchos privilegios y exenciones al concejo, e intervino en sus contiendas jurisdiccionales con la Iglesia a favor de aquel ${ }^{43}$. Ello no impidió, sin embargo, que los eclesiásticos recibieran diferentes mercedes del rey, sobre todo en época tardía, cuando Pedro I deseaba evitar la toma de postura de la Iglesia leonesa a fa $u r$ de Enrique de Trastámara $^{44}$. En cualquier caso, lo que aquí interesa es la postura adoptada por el monarca ante las sentencias de excomunión por parte del obispo leonés, y ésta no fue otra que oponerse al prelado, según consta en la provisión del rey fechada en Sevilla el 15 de octubre de 1359, en la que manda al obispo y a los vicarios de la Iglesia leonesa que desagravien a los regidores y cogedores del cobro de "cannamas" a los carniceros de la Iglesia; y que en adelante no vuelvan a poner sentencias de excomunión contra sus justicias y oficiales ${ }^{45}$.

En otro orden de cosas, también es de interés la provisión de Pedro I de 1353 a los alcaldes, alguacil, caballeros y hombres buenos de Toledo concediendo que suspendan las demandas de las penas y caloñas a los "descomulgados" según el ordenamiento hasta que se haga otro nuevo ${ }^{46}$.

\footnotetext{
${ }^{42}$ Sobre ambas jurisdicciones y la conflictividad en tiempos anteriores ver C. ESTEPA, Estructura social de la ciudad de León (siglos XI-XIII), p. 489; y J.M. NIETO SORIA, Los obispos de la diócesis de León en sus relaciones con la monarquía, 1250-1350. "Archivos Leoneses", 74 (1983), pp. 240-246.

${ }^{43}$ Así, en 1350, Pedro I prohibió los apremios del obispo a los arrendadores de las fincas de su señorío, A.M. León, doc. 97; y obligó al cabildo a devolver al concejo las heredades que había adquirido en el valle de la Valdovina, A.M. León, doc. 98.

${ }^{44}$ Sobre las concesiones al clero ver PÉrez LlamazARES Catálogo de los códices y documentos de la Real Colegiata de San Isidoro de León, León, 1923; GARCía VILLADA, Catálogo de los códices y documentos de la catedral de León, Madrid, 1919; e I. GonZÁlez GALLEGO, La ciudad de León en el reinado de Pedro I y ante el proceso de ascensión al trono de Enrique de Trastámara, "Archivos Leoneses", 65 (1979), pp. 9-73.

${ }^{45}$ A.M. León, doc. 128.

${ }^{+6} \mathrm{BN}$, Ms. 13.100, fol. 122 r.-v. Los conflictos por diversas causas con los excomulgados en Toledo fueron casi constantes. Valga como ejemplo la orden de Enrique II en 1371 ante la petición del cabildo para que los excomulgados se abstuvieran. so grave pena, de asistir a los oficios divinos. BN, Ms. 13.101, fols. $132 \mathrm{r}$. $-133 \mathrm{r}$.
} 
Análisis aparte merece, por sus connotaciones claramente políticas, el entredicho lanzado por el obispo de Cartagena, don Alfonso de Vargas, contra el concejo de Orihuela. Se trata de un caso singular por el verdadero trasfondo político del mismo. Don Alfonso de Vargas, si bien es cierto que en ocasiones de nada sirvieron sus protestas frente a algunos favores concedidos por Pedro I al concejo murciano, también lo es el que, por lo general mantuviera buenas relaciones con este monarca ${ }^{47}$. Así, en el transcurso de la guerra con Aragón, cuando el concejo oriolano, ante las noticias del asedio de las tropas castellanas, mandó sacar el trigo suficiente del granero para levantar un muro defensivo, el obispo puso en entredicho a Orihuela. El alzamiento del mismo no se llevaría a efecto, según carta del prelado al concejo, hasta "ser satisfecha la iglesia de todo lo que fue tomado assi de pan como en dineros, que nos no somos tenudos a pagar ninguna cosa en estas obras" ${ }^{48}$. Pero en este asunto, según ya ha sido planteado, no es fácil separar el componente puramente defensivo de los bienes de la Iglesia, causa aducida, del político que este prelado podía tener al hallarse su rey en guerra con el de Aragón ${ }^{49}$.

Del tercer tipo de intervenciones reales en materia de excomunión que hemos presentado, existe un claro ejemplo en la carta enviada por Pedro I el 30 de marzo de 1351 al arzobispo de Toledo, don Gonzalo, ordenándole, ante la querella presentada por el prior Toribio Fernández, que no demandase a la Iglesia de Guadalupe el pago de servicios al estar exenta de ellos, y que quitase la sentencia de excomunión impuesta a sus clérigos. El final de la carta es amenazador: si el arzobispo no le obedece, el monarca le

\footnotetext{
${ }^{47}$ El prelado obtuvo, por ejemplo, carta de Pedro I sobre diezmos, así como el que se retirara la orden de los almojarifes de Murcia y Molina Seca para que no cobrasen alquilate a los moros del señorío eclesiástico de Alguazas, Alcantarilla y Arrixaca, CODOM, XII, docs. $30,54,55,56,58,59$ y 82 . Sus buenas relaciones pueden apreciarse también por la confianza que demostró Pedro I en el prelado al encargarle el traslado de la reina Isabel desde Hellín a Murcia en 1364 y ponerle al frente de la escolta de cien caballeros y doscientos ballesteros murcianos, CODOM, VII, doc. 113. Igualmente el prelado, como después analizaremos, contribuyó en los gastos de la guerra con Aragón.

${ }^{4 x}$ Sobre estos acontecimientos ver P. Bellot, Anales de Orihuela, 1622, I, pp. 33 y 35: y Díaz Cassou, Serie de obispos de Cartagena, pp. 37-38.

${ }^{+1}$ Ver al respecto I. SANZ SANCHO, Iglesia de Cartagena-Murcia en el s. XIV. "Hispania Sacra”, (1986), pp. 27-28.
} 
mandaría pagar todo doblado, además de imponerle una pena de seiscientos maravedíes ${ }^{50}$.

Contamos, asimismo, con un representativo ejemplo del cuarto y último caso de intervenciones apuntadas. Se trata de la excomunión lanzada en 1368 por el obispo de Cartagena don Nicolás de Aguilar al concejo murciano. Como hemos podido ir comprobando en otras ocasiones, conforme avanzaba el tiempo, muchos personajes se fueron pasando del bando legitimista al de Enrique de Trastámara. Uno de ellos fue don Nicolás de Aguilar, quien junto a don Pedro López de Ayala, capitán mayor de guerra de la frontera, y Diego Alfonso de Tamayo, nombrado regidor de Murcia por Pedro I en 1366, habían organizado desde Aragón una campaña política y militar contra el reino murciano, fiel a la soberanía de Pedro I ${ }^{51}$. Además de ésto, el obispo cartaginense lanzó una ofensiva espiritual decretando la excomunión en todo su obispado a quienes ayudaran al monarca. La sentencia de excomunión fue en seguida puesta en conocimiento de Pedro I, quien en 1368 envió dos cartas al concejo murciano comunicándoles que hiciesen caso omiso de dicha excomunión ya que don Nicolás estaba "desobediente al rey", y ordenándoles que hicieran saber a los clérigos que tampoco debían observar la censura y entredicho puestos por el obispo de Cartagena, y que siguieran celebrando misas. De no hacerlo así, continúa la carta, los habitantes de Murcia no deberán entregarles los diezmos ${ }^{52}$.

\section{CONFLiCTOS DE LARGA DURACIÓN}

Atendiendo al conjunto de la documentación conservada en torno a las quejas y protestas enviadas a Pedro I sobre diferentes asuntos estrechamente vinculados a los conflictos mantenidos entre concejos y prelados, se pueden apreciar dos actitudes bien diferenciadas según ya hemos ido

\footnotetext{
${ }^{50}$ El documento ha sido publicado por fray D. ECIJA, Libro del monasterio de Guadalupe, Cáceres, 1953, pp. 78-79; y M.F. CERRO HERRANZ. Documentación del monasterio de Guadalupe. Siglo XIV, Cáceres, 1987, doc. 33, pp. 32-33.

'IVer J. TORRES FonTES, El concejo murciano en el reino de Pedro I, p. 265; y L.V. Díaz MARTín, Los adelantados, p. 36.

${ }^{52}$ A.M. Murcia, Cartas Reales, Eras 1405-1418, fol. 12. ARAH, Col. Morales, XII, fol. 124. BN, Ms, 13.075, fol. 210 v.
} 
comprobando, y en función de quiénes formularan la protesta. Por un lado, los concejos denunciaban una y otra vez los abusos e infracciones perpetrados por el clero - menoscaban la jurisdicción real; los clérigos y sus excusados eluden los servicios y contribuciones a los que están obligados; cada día se incrementa el número de sus paniaguados; apresan a laicos indebidamente; emplean abusivamente el arma de la excomunión, etcétera. Por otro los eclesiásticos acusan a los laicos de irreverentes en el sentido más amplio del término y de arremeter contra sus personas, bienes y privilegios sin ni siquiera inmutarse ante la amenaza de la excomunión.

Al margen de las protestas de carácter general ya analizadas, ahora vamos a ocuparnos tan solo de aquellas contiendas que se fueron configurando y desarrollando a lo largo de un extenso período de tiempo y que, además, tuvieron lugar en ciudades de señorío episcopal ${ }^{53}$. Son varias las fuentes cronísticas que tienen dedicadas un importante número de páginas al relato de los diferentes enfrentamientos protagonizados por prelados y concejos de ciudades episcopales a lo largo del Medievo en tierras de la corona castellana, por lo que consideramos innecesario analizar detenidamente los orígenes de cada uno de ellos, ya que, además, algunos han sido objeto de estudio por diferentes historiadores. Solo profundizaremos, pues, en los términos en que se plantearon tales conflictos durante el reinado de Pedro I, así como la actitud de este monarca ante cada uno de ellos para precisar, al fin, hasta qué punto su política concejil puede o no ser entendida conjuntamente con la de sus predecesores y sucesores en el trono.

\section{A. Palencia}

Si bien es cierto que, como después veremos, hubo otros señoríos episcopales castellanos en los que la intervención de Pedro I y, en general, de todos los monarcas bajomedievales resultó habitual ante los diversos brotes de tensión y violencia producidos entre los concejos y sus obispos, no

\footnotetext{
${ }^{53}$ Según ya hemos visto, hubo otros conflictos también de larga duración que no se produjeron en ciudades de señorío episcopal, como por ejemplo los antes mencionados de León o Murcia.
} 
cabe duda de que en el caso palentino dicha intervención fue especialmente incesante, por no decir ininterrumpida ${ }^{54}$.

No es necesario hablar aquí de las atribuciones y derechos propios del titular de este señorío ${ }^{55}$, ni analizar cada uno de los acontecimientos que jalonaron las relaciones entre el poder señorial y el concejo palentinos a lo largo del medievo ${ }^{56}$. Lo que sí parece oportuno es subrayar que los problemas y enfrentamientos entre este concejo y su obispo aparecen desde los mismos inicios de la historia de este señorío. No obstante, fue el reinado de Alfonso X el que marcaría el comienzo de una larga cadena de conflictos cuya máxima intensidad se halla en los años de gobierno de sus inmediatos sucesores, manteniéndose vigente hasta el reinado de Enrique IV.

Los puntos de tensión entre concejo y obispo palentino habían sido hasta entonces y seguirían siéndolo, por lo general, de carácter físcal y administrativo ${ }^{57}$. En cuanto a las diversas actitudes presentadas, hemos de decir que los prelados a lo largo de las centurias bajomedievales defendieron por todos los medios sus prerrogativas señoriales e, incluso, pretendieron acrecentar sus poderes sobre el concejo hasta el punto de arrogarse derechos que no les correspondían. Por su parte, el concejo deseó siempre sacudirse la dependencia señorial o, al menos, aumentar en lo posible su escasa autonomía. Por último, la monarquía intentó mantener un estrecho control sobre el gobierno de la ciudad, manifestado en un progresivo intervencionismo.

\footnotetext{
${ }^{54}$ Sobre el desarrollo de los acontecimientos palentinos, de la guerra entre el concejo y su señor, y la intervención de la monarquía en ellos ver R. CARANDE, El obispo, el concejo y los regidores de Palencia (1352-1422). Aportación documental sobre el gobierno de una ciudad en la Edad Media, Barcelona, 1969; J.M. NiETo SoRIA, La relación de poderes en un señorío eclesiástico de ámbito urbano: Palencia, 1280-1305, en "La ciudad hispánica durante los siglos XIII al XVI", Madrid, 1985; A. ESTEBAN RECIO, Elecciones concejiles en Palencia a fines de la Edad Media: la pugna entre el obispo y la ciudad, en "Actas del I Congreso de Historia de Palencia”, II, Palencia, 1987, pp. 553-579; y ARRANZ GuZMÁN, Los enfrentamientos, pp. 5-68.

${ }^{55}$ Concretamente en el Libro famoso de las Behetrias de Castilla que se custodia en la Real Chancillería de Valladolid, Santander, 1866, se dice sobre Palencia que "es lugar del obispo de la Iglesia de Palencia" y que los derechos del prelado son: por marzo pagar algunas casas ocho dineros, otras cuatro y otras nada. El portazgo es en sus dos tercios del obispo y el restante del cabildo, fols. 43 v. $-44 \mathrm{r}$.

${ }^{56} \mathrm{Me}$ remito aquí a mi estudio antes citado, Los enfrentamientos, en concreto a las pp. 8-21.

${ }^{57} \mathrm{El}$ que desde 1175 cuarenta familias judías pasaran a depender jurídicamente del señorío del obispo y que ocurriera lo mismo con los musulmanes en 1177, implicaba que ambas comunidades contribuyeran conjuntamente con los habitantes cristianos. También resultaba conflictivo el elevado número de excusados del obispo y los canónigos. Otro motivo de fricción era la provisión de cargos para la administración y gobierno del territorio señorial.
} 
El último incidente grave del que se tiene noticia antes de la subida al trono de Pedro I data de 1319. Los acontecimientos fueron los siguientes: los alcaldes de la ciudad insultaron y agredieron al obispo don Gómez; ante tal agravio los tutores de Alfonso XI condenaron a muerte a cuarenta ciudadanos principales de Palencia, confiscándoles sus bienes que fueron entregados al prelado ${ }^{58}$. A partir de este enfrentamiento, y tras alcanzar su mayoría de edad, Alfonso XI iniciaría una política claramente intervencionista sobre el gobierno de Palencia a través, por un lado, de reforzar el señorío del obispo sobre la ciudad y, por otro, asegurándose que los titulares fuesen prelados muy allegados a la familia real. Lo que se intentaba con ello, en definitiva, era que "los obispos palentinos acabaran actuando como verdaderos agentes de los monarcas castellanos" $" 59$.

Las primeras noticias de interés durante el reinado de Pedro I datan del pontificado del obispo don Vasco (1343-1353), hermano del camarero del monarca, Gutiérrez, canciller de la reina doña Catalina, notario mayor de León, y luego arzobispo de Toledo desde $1353^{60}$. Sabemos que asistió a las cortes vallisoletanas de 1351 gracias a la crónica ${ }^{61}$. Durante la celebración de dichas cortes, don Vasco recibió la confirmación de varios privilegios de monarcas anteriores, así como otros nuevos, tales como la exención del yantar ${ }^{62}$. Pero, pocos meses después, estando todavía reunidas las cortes, Pedro I, recibiría la queja del concejo palentino ante el agravio que les suponía el privilegio que había dado el monarca al prelado, en el que se reconocía a don Vasco el derecho a nombrar de ocho a doce hombres buenos para que, junto con los alcaldes, administrasen el gobierno de la ciudad. Sin embargo, lo que realmente parece que suscitó la reacción del concejo no fue tanto el carácter general de tal medida, sino el que en dicho privilegio no se especificara que la elección hubiese de recaer sobre vecinos de la ciudad ${ }^{63}$. La protesta de 1352 traería consigo la instauración de un régimen para designar a las personas encargadas del gobierno, que subsistiría a lo largo

\footnotetext{
${ }^{58}$ A. FERnÁNDEZ DE MADRID, Silva Palentina, p. 219.

${ }^{59}$ NiETO SORIA, Iglesia y poder real, p. 182.

"Sobre sus datos biográficos ver FERNÁNDEZ DE MADRID, Silva Palentina, p. 240 y ss.; y J.F. RIVERA RECIO, Notas sobre el episcopado palentino en los siglos XIII y XIV, "Anuario de Estudios Medievales", 9 (1974-1979), pp. 407-424.

${ }^{61}$ Crónica de Pedro I, p. 417.

"2.A.C. Palencia, Arm. III, leg. 3, no 17, 19, 21 y 22.

${ }^{\left({ }^{3} \mathrm{E}\right.} \mathrm{El}$ documento fue publicado por CARANDE, El obispo, el concejo, pp. 14-17.
} 
de los siglos XIV y XV. Pero los disturbios no cesaron. Prueba de ello es que pocos meses después, concretamente en agosto de 1352, Pedro I se vio obligado a mandar al adelantado y merino de Castilla que fuesen a prestar ayuda a don Vasco para poner fin a las luchas y banderías de gentes armadas que provocaban constantes tumultos en la ciudad ${ }^{64}$. Los enfrentamientos, sin embargo, siguieron siendo incesantes hasta el punto que el propio pontífice Inocencio VI se vio obligado a tomar cartas en el asunto. Así, el 2 de junio de 1354, un año después de haber tomado posesión de la sede Reginaldo de Maubernard, tesorero y familiar del papa, Inocencio VI envió dos cartas al rey castellano, una agradeciéndole el donativo de doce mil maravedíes que había hecho a la Iglesia palentina, y otra poniéndole en guardia sobre las intenciones del concejo de Palencia de atentar contra los derechos de la Iglesia palentina, y rogándole que no les concediera cosa alguna sin escuchar previamente al vicario y oficial del obispo. En la misma fecha, el pontífice envió una tercera carta al concejo de Palencia, rogando su sometimiento a los vicarios y oficiales de Reginaldo de Maubernard ${ }^{65}$.

De poco sirvió, no obstante, la intervención pontificia, ya que en 1356 las graves contiendas entabladas a causa de la ampliación del número de excusados del cabildo catedral llevarían a éste a decretar la interdicción de los oficios divinos. El nuevo obispo, don Gutierre Gómez, puso fin a esta querella $^{66}$. Pero ni él ni sus sucesores conseguirían zanjar definitivamente el asunto. Prueba de ello fueron no sólo los continuos brotes de violencia que se vivieron en esta ciudad a lo largo de los reinados posteriores, sino también hechos tan significativos como el que desde el reinado de Enrique II hasta el de Enrique IV unas veces asistiera a cortes el prelado titular y otras los representantes del concejo ${ }^{67}$.

\footnotetext{
${ }^{6+}$ A.C. Palencia, Arm. II, leg. II, no 9

${ }^{69}$ El nombramiento del prelado en A. Secreto Vaticano, Registro Vaticano, vol. 243, fol. 244 r. Los tres documentos están recogidos por ZUNZUNEGUI ARAMBURU, Bulas y ciartas secretas de Inocencio VI, docs. 99, 100 y 101, pp. 110-112.

${ }^{\text {"ch }}$ Sobre el tema ver CARANDE, El obispo, el concejo, p. 20

${ }^{67}$ Esta irregularidad nos ha llevado a considerar que lo que determinaba la presencia o ausencia de los representantes de un concejo de señorío eclesiástico en lugar del prelado, dependió no tanto de la existencia de una norma establecida (V. PISKORSKI en su obra Las Cortes de Castilla en el periodo de tránsito de la Edad Media a la Edad Moderna, 1188-1520, afirmó que las ciudades de señorío no acudían a cortes con sus procuradores, sino que estaban representados por sus respectivos señores) sino de la fuerza o debilidad que podía presentar un concejo en un momento determinado, así como de los intereses particulares de la monarquía en ese mismo momento.
} 


\section{B. Illescas}

Aunque el arzobispo de Toledo no tenía señorío sobre la propia sede arzobispal, sí lo disfrutaba sobre muchas villas importantes de la archidiócesis, como Alcalá de Henares, Illescas, Uceda, Talavera o Brihuega ${ }^{68}$. Algunas de ellas, en especial Illescas, fueron escenario de constantes enfrentamientos entre vecinos y primados, motivados por su descontento de ser tierras de señorío episcopal.

Las peticiones de ayuda a los monarcas por parte de los arzobispos de Toledo con el propósito de proteger su señorío de Illescas, así como las protestas del concejo, que no reconocía el señorío arzobispal y capitular sobre la villa, no eran cosa nueva. Ya en el año 1291, los de Illescas se habían negado a reconocer el señorío del arzobispo don Gonzalo García Gudiel, basándose en un privilegio que Sancho IV les había otorgado con fecha 22 de agosto de $1291^{69}$. En esta ocasión la victoria fue del prelado, quien, tras acudir al rey a fin de que protegiera sus intereses sobre la villa, recibió su respaldo al precisar que el privilegio en el que se basaban los del concejo no implicaba la anulación de los derechos del arzobispo. Sin embargo, según ya analizamos en otra ocasión ${ }^{70}$, la decisión real sólo fue respetada en teoría y por cierto tiempo, como lo demuestran las quejas que en este sentido se elevaron en las cortes de Medina del Campo de 1302 y en las de Valladolid de $1322^{71}$. En estas últimas, los de Illescas protestaron de los abusos perpetrados por el arzobispo, quien había llegado a encarcelar a "cavalleros e ommes bonos de Yliescas". Por fin, y ante la confirmación del enfrentamiento, Alfonso XI, el 11 de febrero de 1329, dictó sentencia, especificando los derechos que debía pagar esta villa al rey y los que debía pagar al arzobispo. Pero todo resultó inútil: los disturbios no cesarían y, en 1345 , el rey se vería obligado a dar otra sentencia ${ }^{72}$.

\footnotetext{
${ }^{68}$ Pérez Villaamil hizo una relación del extenso territorio logrado acumular por los arzobispos toledanos durante el medievo en su estudio El señorio temporal de los obispos de España en la Edad Media, "Boletín de la Real Academia de la Historia", 66 (1916), pp. 388389.

${ }^{69} \mathrm{BN}, \mathrm{Ms} .13 .095$, fol. 50 r.-v.

${ }^{70}$ ARRANZ GuZmÁN, Los enfrentamientos, pp. 21-27.

${ }^{71}$ Cortes, I, pp. 262-263 y 365.

${ }^{72}$ ARAH, Col. Abella, XVIII; y BN, Ms. 1.398, fols. 102 r-111 v. En esta nueva sentencia Alfonso XI delimitó los derechos que en la villa correspondían al rey como rey y a la Iglesia como señor.
} 
Desconocemos, por falta de documentación, si desde 1345 hasta la subida al trono de Pedro I el concejo de Illescas volvió a cuestionar el señorío del arzobispo y del cabildo sobre la villa. Tampoco contamos con el necesario número de documentos como para poder precisar la trayectoria exacta que siguió el enfrentamiento durante este reinado, pero sí el suficiente como para saber que el conflicto permaneció vigente. Todo hace pensar que el hecho de que los de Illescas no presentaran nuevas quejas ante Pedro I en los primeros meses de su reinado se debió al hecho de que el titular de la archidiócesis era don Gil de Albornoz, y que éste, nada más acceder al trono el nuevo monarca abandonara la Península para instalarse en la corte pontificia y ser nombrado cardenal de Santa Práxedes el 17 de diciembre de $1350^{73}$. De su sucesor en la archidiócesis, don Gonzalo de Aguilar (13511353), apenas quedan noticias salvo las referentes a su trayectoria eclesiástica como obispo primero de Cuenca y luego de Sigüenza y, finalmente, como arzobispo de Compostela ${ }^{74}$. Alguna más existe del titular posterior, don Vasco Fernández de Toledo, quien tendría que acabar sus días en Coimbra en 1362 a causa de las sospechas de conspirador que Pedro I tenía por el hecho de ser el prelado hermano de don Gutierre, a quien el rey había mandado ajusticiar. No obstante, hasta esos momentos finales, el monarca, según lo demuestran algunas de sus provisiones, había ayudado siempre al arzobispo ${ }^{75}$. Sin embargo, nos consta por otra provisión real que durante el gobierno de don Vasco en la archidiócesis los conflictos con los de Illescas se mantuvieron por diferentes motivos, tales como el que en 1354 los del concejo proveyeran sobre el oficio de alguacil de Illescas sin tener en cuenta el privilegio del cabildo de la Iglesia toledana ${ }^{76}$.

\footnotetext{
${ }^{73}$ Sobre este personaje existen numerosos estudios, como el de BENEYTO, El cardenal Albornoz, Madrid, 1986.

${ }^{74}$ J.F. RIVERA RECIO, Los arzobispos de Toledo, p. 88.

${ }^{75}$ Sirvan como ejemplo la carta enviada el 8 de mayo de 1357 a los alcaldes y alguaciles de Toledo ordenándoles que ayudaran a don Vasco a cobrar ciertos impuestos que algunos moros y judíos se negaban a pagarle (AHN, Clero, carp. 3.022, $\mathrm{n}^{0} 12$, inserto en un documento de 1359); o la dirigida por el arzobispo ante el hecho de que elevados personajes compraban tierras de abadengo dependientes del arzobispo y cabildo toledanos (AHN, Clero, carp. 3.028, $\mathrm{n}^{\circ} 20$; y BN, Ms. 13.100, fols. 160-162 y 164-167)

${ }^{76}$ A.C. Toledo, O. 7. A. 3. 11.
} 
Las variables relaciones mantenidas entre Pedro I y el próximo arzobispo, don Gómez Manrique ${ }^{77}$, hacen sospechar en un tira y afloja constante entre el prelado y el concejo de Illescas, aunque de escaso eco a causa de la situación de guerra civil padecida, por la que muchas tensiones particulares aparecen desdibujadas. A pesar de ello, sin embargo, éstas permanecieron a lo largo de todo el período analizado. De ahí que en 1369 el arzobispo solicitara a Enrique II la confirmación de este señorío ${ }^{78}$. El nuevo monarca no dudaría en concedérselo, junto a la donación de Talavera, el 25 de junio de ese mismo año, como compensación de los servicios prestados por don Vasco a la causa trastamarista ${ }^{79}$.

\section{Sigüenza}

A partir del año 1252 , en que los del concejo seguntino se alzaron contra su obispo, llegándole a encarcelar, sin tener en consideración el compromiso contraído por su juramento de homenaje ${ }^{80}$, los monarcas sucesores de Fernando III, muy especialmente Alfonso XI, hubieron de intervenir en diferentes ocasiones para que los vecinos respetasen el señorío del prelado. Sin embargo, a pesar de la larga duración de su enfrentamiento, éste nunca fue planteado en cortes por los procuradores de las ciudades. Según ya analizamos en otra ocasión, creemos que la causa de ello fue la concurrencia prácticamente constante de los prelados seguntinos en las asambleas del reino ${ }^{81}$. Pensemos, por ejemplo, en don Simón Girón de Cisneros, presente en las de 1302, 1307, 1313 y 1315, quien en todas ellas consiguió la confirmación de sus privilegios ${ }^{82}$; o en don Juan, abad de Salas, que aunque en 1365 se hallaba en pleitos con el concejo, asistiría a las

\footnotetext{
${ }^{77}$ Sobre las mismas ver mi artículo Un personaje y un episodio de la guerra civil castellana: el arzobispo D. Gómez Manrique y el ordenamiento de Toledo de 1366, "Anuario de Estudios Medievales", 18 (1988), pp. 309-322.

${ }^{78}$ Entre los servicios prestados, según ya analizamos en nuestro artículo antes citado, el arzobispo había sido elegido por Enrique de Trastámara en 1366, según figura en el ordenamiento del ayuntamiento que éste realizó en Toledo, para encargarse de administrar la ciudad.

${ }^{79} \mathrm{~J}$. GÓMEZ MENOR, La antigua tierra de Talavera. Bosquejo histórico y aportación documental, Toledo, 1965; y S. DE Moxó, Los antiguos señoríos de Toledo, Toledo, 1973.

${ }^{80} \mathrm{~T}$. Minguella, Historia de la diócesis de Sigüenza y sus obispos, 3 vols., Madrid, 1912, doc. CCV, pp. 567-568.

${ }^{81}$ ARRANZ GUZMÁN, Los enfrentamientos, pp. 62-63.

${ }^{82}$ Minguella, Historia de la diócesis, pp. 2-22.
} 
cortes de 1367 y 1371, en las que Enrique II le confirmaría sus privilegios $y$ franquezas ${ }^{83}$. No ha de olvidarse tampoco que algunos de los prelados seguntinos eran parientes de miembros de la realeza, y que un buen número de ellos desempeñaron diferentes cargos de carácter extraeclesiástico en la corte.

El último conflicto grave acaecido antes de la llegada al trono de Pedro I se había producido en 1331 al rebelarse de nuevo los del concejo contra el señorío del obispo y del cabildo. La postura adoptada por Alfonso XI estuvo llena de astucia: tras abrir una pesquisa y comprobar los resultados, dictaminó por un lado que sobre la ciudad poseían señorío el obispo y el cabildo, por lo que los habitantes debían prestarle pleitohomenaje, además de respetarle su derecho a atender los pleitos de alzada y guardar las llaves de la ciudad; pero por otro, también reconoció que el señorío de la ciudad pertenecía al monarca por todos los derechos reales que tenía en ella. En la sentencia del 6 de enero de 1331 el rey precisó con toda claridad los tributos pertenecientes al señor:

\footnotetext{
el pecho forero que es dos maravedis e un sueldo vieio cada anno por el Sant Miguel del mes de septiembre de cada vecino segun que lo usaron fasta aqui. Et el portazgo que es de todo esto la mitad del obispo et la meatad (sic) del cabildo, et las calonnas que se partan en esta manera el tercio al obispo et el tercio al querelloso et el tercio a los alcaldes. Otrosi la renta de la carneceria et de los almudes et del peso que pertenece todo al dicho obispo.
}

Además de dichos tributos, el señor cobraba otros impuestos: almotanazgo del vino, impuesto del vino, paso del ganado, etc ${ }^{84}$.

En definitiva, lo que Alfonso XI pretendía, como ha apuntado J.M. Nieto, "era aprovechar la ocasión para que, sin perjudicar la permanencia del señorío del obispo y del cabildo, hacer ver que también él poseía ciertos derechos sobre la ciudad, como, de hecho, sucedía en otros lugares de señorío eclesiástico en que también los monarcas tenían reservados ciertos derechos" $"$.

\footnotetext{
${ }^{83}$ Ibídem, doc. 121 , pp. 566-568.

${ }^{8+}$ Ibidem, doc. 69, pp. 487-490. Sobre las cargas señoriales y los derechos reales ver A. Blázquez CARBAJOSA, Impuestos y cargas en el señorío episcopal seguntino, "Anales Seguntinos" (1984), pp. 47-63.

${ }^{85}$ NiETO SORIA, Iglesia y poder real, p. 182.
} 
Desde el reinado de Pedro I, los conflictos en el concejo seguntino permanecieron vigentes a lo largo del pontificado de los tres prelados que en estos años ocuparon la sede: Pedro Gómez Barroso (1348-1358), Juan Lucronio (1358-1361), y Juan, abad de Salas (1361-1375). Ahora bien, en los enfrentamientos mantenidos entre el concejo de Sigüenza y los sucesivos titulares de la diócesis, así como en la postura adoptada por Pedro I ante ellos, ha de tenerse en cuenta, probablemente más que respecto a otros conflictos, la situación política vivida en el reino, ya que los condicionó decisivamente.

En un principio, como lo demuestran la confirmación de todos los privilegios, donaciones, exenciones y franquicias hechas por el monarca en favor de la Iglesia seguntina durante la celebración de las cortes de 1351, todo parecía indicar que Pedro I iba a defender, al igual que su padre, el señorío del obispo don Pedro Gómez Barroso ${ }^{86}$. Pero los acontecimientos políticos posteriores, así como la postura de enfrentamiento al monarca adoptada por el prelado, harían virar de forma total la situación en la ciudad. Desafortunadamente existen muy pocos documentos en relación con los problemas del concejo acaecidos en este reinado, aunque sí los suficientes para saber que entre la boda de Pedro I y Blanca de Borbón (1353) y la excomunión del rey en Toledo por el delegado papal, el obispo de Senez (1354), Gómez Barroso había perdido el favor real. No cabe duda de que el primer paso propiciatorio para el enfriamiento de relaciones entre el rey y el obispo fue dado por éste, ya que se sabe que el 18 de agosto de 1353 Gómez Barroso se hallaba ya en la corte de Aviñón rogando a Inocencio VI que interpusiera su autoridad a fin de apartar a Pedro I de María de Padilla y de unirle a su legítima esposa Blanca de Borbón, de quien, durante algunos meses, junto al caballero toledano don Tello Palomeque, sería custodio en su prisión de Arévalo ${ }^{87}$.

La represalia del rey fue inmediata: despojó de sus bienes y señorío al prelado, quien además fue reducido a prisión en el castillo de Aguilar de Campoo, y en 1355 utilizó el alcázar de los obispos seguntinos para dejar prisionero en él a doña Blanca. La crónica lo cuenta detalladamente al relatar los acontecimientos del año 1355:

\footnotetext{
${ }^{81}$ Minguella, Historia de la diócesis, docs. 107 y 108.

${ }^{87}$ Ibidem, p. 61. Ver también MARTínEz GómEZ-GoRdo, Doña Blanca de Borbón, reina de Castilla, y su prisión en el castillo de Sigüenza, "Anales Seguntinos", (1986), pp. 11-44.
} 


\begin{abstract}
E dende a quatro dias mando el rey a Juan Ferrandez de Henestrosa, su camarero mayor, que levase a la dicha reyna donna Blanca al alcazar de la villa de Siguenza, que le tenia el dicho Juan Ferrandez, ca el obispo de Siguenza, que era natural de Toledo, tomarale ese dia el rey, e teniale preso, por quanto andaba en esta demanda con el conde don Enrique e con el maestre don Fadrique. E a este dicho obispo decianle don Pedro Gomez Barroso, que despues fue cardenal: e todo lo suyo fue tomado e robado, e los castillos del obispado de Siguenza suyos mandolos el rey guardar a Juan Ferrandez de Henestrosa ${ }^{88}$.
\end{abstract}

La crónica también señala cómo en ese mismo año Guillermo de la Jugue, legado papal, se entrevistó en Toro con Pedro I obteniendo de él la libertad del obispo seguntino a cambio de retirar el entredicho que se había puesto sobre el reino de Castilla en $1354^{89}$. Gómez Barroso marchó entonces a Aviñón para unirse a Gil de Albornoz y formar parte del frente antipetrista que el cardenal había configurado en la corte pontificia, hasta ser nombrado obispo de Coimbra.

Sin lugar a dudas los problemas generales del reino, unidos al enfrentamiento mantenido entre Pedro I y el obispo, y a la posterior marcha del prelado a Aviñón, hicieron posible que el concejo seguntino viviera tiempos tranquilos sin presiones señoriales. Desgraciadamente, sin embargo, la escasez de documentación sobre estos años impide hacer mayores precisiones. Lo único que sabemos de su sucesor en la sede, don Juan Lucronio, al acceder a ella en 1358, es que recobró el señorío de la ciudad, su castillo, y que, probablemente, bien para evitar enfrentamientos con el nuevo titular o bien por la inseguridad fronteriza de Sigüenza en la guerra con Aragón, Pedro I decidió trasladar a doña Blanca de su prisión en el alcázar de Sigüenza a la de Jerez de la Frontera en 1359.

Si tras la recuperación de su señorío hubo disturbios es algo que desconocemos; pero lo que sí se puede suponer en función de los documentos emitidos durante el pontificado de su sucesor don Juan de Salas, según podremos comprobar, es que el prelado y el cabildo tuvieron problemas a la hora de percibir los diezmos que les correspondían.

De las relaciones de don Juan de Salas con el concejo quedan, por el contrario, algunos documentos que certifican la permanencia de litigios por la cuestión del señorío de la ciudad. En los primeros contactos del nuevo

\footnotetext{
${ }^{88}$ Crónica de Pedro I, p. 464.

${ }^{8 y}$ Ibidem, p. 468.
} 
prelado con los ciudadanos no hubo dificultades, ya que éstos le prestaron homenaje al mismo tiempo que le entregaban las llaves de la ciudad en reconocimiento del señorío ${ }^{90}$. Sin embargo, la paz no debió ser duradera, según puede deducirse por los pleitos que los del concejo llevaron ante el rey acerca del señorío de la ciudad. La victoria volvió a ponerse del lado del prelado en 1365 , cuando los ciudadanos confesaron en su presencia y en la del cabildo, al igual que lo hicieron la primera vez que don Juan pisó la capital de su diócesis, que, en efecto, el obispo y el cabildo eran los señores de Sigüenza ${ }^{91}$.

El hecho de que desde el año 1366 los seguntinos reconocieran por rey a Enrique de Trastámara impide conocer cuál hubiera sido la actitud que desde entonces Pedro I hubiera adoptado respecto al conflicto por el señorío en caso de hubieran permanecido fieles a su causa. Don Juan de Salas, como gran parte del episcopado castellano, vio conveniente apoyar a don Enrique. El obispo estaba en lo cierto, según lo demuestra el hecho de que en la asamblea que éste celebró en Burgos en 1367, en vida aún de Pedro I, el Trastámara, intitulándose ya rey de Castilla, enviara una carta a los alcaldes y alguacil de la ciudad así como a los oficiales de las villas y aldeas del obispado para que pagaran al prelado y cabildo los cuatro mil maravedíes anuales más los atrasos por diezmos de las salinas de Atienza que aún no había logrado cobrar ${ }^{92}$. Una vez más, los conflictos ciudadanos quedan desdibujados a causa de la guerra civil.

\section{Santiago de Compostela}

Salvo raras excepciones las ciudades gallegas eran, como en el caso de Santiago, de jurisdicción eclesiástica con una larga tradición, siendo la monarquía la principal sustentadora de los señoríos episcopales cuando los prelados entraban en litigio con sus respectivos concejos. Ahora bien, el apoyo de los sucesivos reyes siempre estuvo condicionado a la existencia de buenas relaciones con el correspondiente titular del señorío. Nunca permitieron que los grandes señoríos eclesiásticos estuvieran en manos de

\footnotetext{
${ }^{90}$ El documento, fechado el 26 de octubre de 1361, está recogido por Minguella, Historia de la diócesis, pp. 559-560.

${ }^{91}$ Ibidem, p. 71.

${ }^{92}$ Ibidem, doc. CXVII.
} 
prelados que no fueran colaboradores.directos de la realeza o, al menos, especialmente afines al monarca de turno ${ }^{93}$.

Antes de analizar el caso concreto de los enfrentamientos acaecidos en Compostela, consideramos oportuno subrayar que en el primer contacto general mantenido entre Pedro I y los procuradores de las ciudades, es decir, las cortes vallisoletanas de 1351, el monarca pudo comprobar hasta qué punto los problemas surgidos entre ciudadanos y eclesiásticos en tierras gallegas eran superiores en número respecto a los de otros territorios, siendo los relativos a intromisiones jurisdiccionales los más abundantemente abordados $^{94}$.

Fueron cuatro los titulares de la archidiócesis durante el reinado de Pedro I: Gómez Manrique, Suero Gómez de Toledo, Alonso Sánchez de Moscoso y Rodrigo de Moscoso.

Tras el constante tira y afloja vivido durante la minoría de edad de Alfonso XI - mientras que el arzobispo Rodrigo de Padrón obtuvo el apoyo de uno de los tutores, don Pedro, y el concejo lo consiguió del otro tutor, el infante don Juan-, una vez alcanzada la mayoría de edad, el monarca confirmó el señorío del arzobispo en 1325. Nuevamente, en 1346, Alfonso XI confirmó el señorío de los arzobispos, pero, entonces, como ya observó López Ferreiro, el rey hizo algunos recortes en materia de justicia ${ }^{95}$. Por este motivo, Pedro I, tendría que oír la siguiente queja en las cortes de 1351:

\begin{abstract}
A lo que me pidieron por merçed porque el rey mio padre, que Dios perdone, dizien que por enformaçion de algunos que le en ello pusieron, que dio algunas sentençias e que agravio la eglesia et el arzçobispo de Santiago e algunas eglesias e perlados de su ssennorio, que dizen quellos tiro algunos llugares e jurisdiçiones non lo deviendo fazer de derecho; e que commo quier que el dicho rey mio padre despues desto se biviera, tirara e desfeziera los dichos agravios, pero que por la muerte que le tan ayna acaesçio que non ovo lugar de lo fazer; e (que) tenga por bien de ver sobresto e que desagravie las eglesias e perllados, sse algund agravio rreçebieron, e les quiera guardar su derecho ${ }^{96}$.
\end{abstract}

\footnotetext{
${ }^{93}$ Sobre la evolución de los señoríos episcopales gallegos desde Fernando III a Enrique IV ver ARRANZ GUZMÁN, Los enfrentamientos, pp. 27-46.

${ }^{94} \mathrm{Ver}$ al respecto las peticiones, 36, 38, 45, 46 y 49, Cortes, II, pp. 68-73.

${ }^{95}$ López Ferreiro, Historia de la Santa A.M. Iglesia, VI, p. 133

${ }^{\%}$ Cortes, II, pp. 44-45.
} 
Sin duda, a la sentencia que se refieren es a la de 1346. La reclamación fue atendida por Pedro I, quien afirmó que haría lo oportuno de acuerdo a derecho. En su resolución debieron pesar las buenas relaciones que mantenía con el nuevo arzobispo don Gómez Manrique, a quien, presente en estas cortes, le confirmaría sus privilegios.

No existen noticias de que don Gómez, ni como prelado ni como estadista, hallara en su gestión tropiezos con Pedro I durante su época de arzobispo compostelano. Todavía en 1362, siendo ya arzobispo de Toledo, y antes de apoyar a Enrique de Trastámara, pronunciaría una larga arenga abogando por la legitimidad del matrimonio del monarca con María de Padilla. Sin embargo, don Gómez no iba a conseguir que las aguas volvieran a su cauce de forma definitiva. También el papa Clemente VI se ocupó de los problemas de este señorío, escribiendo en 1352 a Pedro I, encareciéndole la restitución del mismo a su titular ${ }^{97}$. Pero lo más importante acaecido en estos primeros momentos fueron las repercusiones que tuvo en Santiago el ordenamiento de menestrales hecho en las cortes vallisoletanas, ya que su contenido iba a dar margen a ciertas dudas en la ciudad. En concreto, sobre los pechos con que los que debían contribuir al concejo los canteros y demás oficiales de la obra de la catedral. El concejo quería someterles al pago de toda clase de pechos, al margen de que fueran o no concejiles. Ante ello, los oficiales reclamaron y el arzobispo y el cabildo volvieron a elevar sus voces ante Pedro I, pidiéndole que aclarara cuáles eran los pechos de los que no se podían excusar. El rey así lo hizo, y el 27 de mayo de 1354, desde Paredes de Nava, dirigió una carta al concejo y justicias de la ciudad de Santiago, manifestándoles que obraban mal al exigir tributos no concejiles a los obreros de la catedral so pretexto del ordenamiento mencionado. A la pregunta sobre cuáles eran los pechos concejiles que los obreros debían pagar, respondió que eran:

puente et foente et en el muro de la villa, et en las velas, et en lavor de las calçadas, et en conpra de termino, et en soldada de juez de fuero. Et que en estos tales, que non deven ser ningunos escusados moradores en la villa de qual ley o condiçion que $\operatorname{sean}^{98}$.

\footnotetext{
${ }^{97}$ Sobre este personaje ver ARRANZ GUZMÁN, Un personaje y un episodio; y LÓPEZ Ferreiro, Historia de la Santa A.M. Iglesia, p. 143.

${ }^{98}$ López Ferreiro, Historia de la Santa A.M. Iglesia, doc. XXVIII, pp. 133-134. Los privilegios e inmunidades de que gozaban los oficiales de la obra de Santiago databan del reinado de Alfonso VII y habían sido confirmados por Alfonso IX, Fernando III, Alfonso X en
} 
Pero a pesar de la mediación del pontífice, la restitución de total del señorío no se llevó a cabo durante el reinado de Pedro I. Hemos de pensar que la situación de guerra civil vivida, y el hecho de que en las cortes burgalesas de 1355 el rey fuera apoyado por las milicias compostelanas, ante la petición de hombres para enfrentarse a las tropas de Enrique de Trastámara, debieron condicionar decisivamente la postura del monarca. Habría que esperar a que accediera al trono Enrique II para que se llevara a cabo dicha restitución en 1369, siendo arzobispo don Rodrigo Moscoso, según consta en un privilegio otorgado el 12 de abril ${ }^{99}$.

Lo que sí confirmó Pedro I en las cortes de 1351 fue un diploma otorgado por Alfonso XI en 1341 que insertaba y ratificaba el de Ramiro I acerca de los votos de Santiago, que algunos lugares se negaban a pagar ${ }^{1(x)}$. Sin embargo, el problema no se solucionaría según puede apreciarse por las quejas elevadas por el procurador del arzobispo en las cortes burgalesas de 1373 y, posteriormente, por la respuesta pública que a esta queja darían los procuradores de las ciudades en las cortes de 1379, al denunciar que el arzobispo obraba "contra derecho"101. También Pedro I otorgó en 1354 otro diploma en favor del arzobispo y cabildo de Santiago, en el que se ordenaba al concejo de la ciudad que no cobrase a la Iglesia el impuesto de vino según se deseaba hacer en virtud de una ordenanza del concejo ${ }^{102}$.

Pero al margen de tales favores a los eclesiásticos compostelanos, lo cierto es que el rey apoyó más al concejo, sobre todo, a raíz de su aportación de hombres para la guerra en 1355 y de las malas relaciones personales que mantuvo con los titulares siguientes ${ }^{103}$.

No se sabe demasiado de los términos en que se desarrolló la elección del arzobispo don Suero Gómez en 1362, pero sí de que el nuevo arzobispo no disfrutó del señorío. Prueba de ello es que fuese el concejo el que en 1363 recibiera la convocatoria regia para asistir a las cortes de

\footnotetext{
1281, y Sancho IV en 1282, López Ferreiro, Fueros municipales, II, pp. 79-81.

"'LÓPEZ FERREIRO, Historia de la Santa A.M. Iglesia, doc. XXX, p. 139.

I(k)Ibidem, VI, p. 142.

${ }^{101}$ Cortes, II, pp. 262 y 290

112-A.C. Santiago, Tumbo B, fol. 282.

${ }^{103}$ Por el apoyo que recibió de las milicias compostelanas, Pedro I otorgó al concejo el que usara como blasón la imagen de Santiago a caballo y ocho leones. También les concedió, a pesar de lo ordenado en las cortes vallisoletanas sobre que todos los escribanos públicos debían extender personalmente todas las escrituras que ante ellos pasasen, que pudieran valerse de escribientes y oficiales para usar de su oficio, según ya antes lo hacían.
} 
Bubierca, y no el arzobispo ${ }^{104}$. Otra prueba más es la mención de alcalde de Santiago por el rey a Esteban Rodríguez Varela, lo que da a entener, como señaló López Ferreiro, "que el arzobispo no tenía el señorío de la ciudad, o que si lo tenía debía de ser muy cercenado" 105.

El apoyo del monarca al concejo favoreció que los caballeros de Santiago hallaran el camino libre para entrar en las heredades de la Iglesia y usurpar todo aquello que desearan, teniendo el cabildo y el arzobispo que tomar medidas al respecto en 1364 y 1365 para que la hacienda eclesiástica no continuara mermando ${ }^{106}$.

De nada iban a servir las medidas adoptadas por don Suero. El arzobispo había caído en desgracia ante el rey. Su nombre se había hecho odioso a Pedro I a causa de ser pariente de Gutierre Fernández de Toledo, quien había invitado a venir a Castilla al infante de Aragón don Fernando y le había prometido, en nombre del monarca, muchas mercedes además del perdón. Sin embargo, lo que más pesó en el ánimo del rey fue, por un lado, el que don Suero enviara sus procuradores a las cortes burgalesas celebradas por Enrique de Trastámara en 1366 y, por otro, y en especial, el obstáculo insalvable que podía suponer el poder del prelado para mantener la soberanía de Pedro I en Galicia ${ }^{107}$. Parece ser que, en principio, el monarca se conformaba con encarcelar a don Suero y tomarle sus fortalezas, pero los consejeros reales pretendían algo más: la muerte del arzobispo. Esta resolución fue la que finalmente se adoptó. Los relatos ofrecidos por la Crónica Abreviada y la Vulgar sobre el asesinato de don Suero perpetrado por Fernán Pérez Churrichao y Alfonso Gómez Gallinato, no coinciden ${ }^{108}$. Según la Crónica Abreviada, el arzobispo y el deán fueron asesinados dentro de la iglesia mientras que el rey y sus acompañantes "daban voces diciendo que non le matasen", lo que no aparece en el texto de la vulgar.

\footnotetext{
${ }^{104}$ El concejo envió como procuradores a Fernán García del Campo y a Arias González a Magallán, donde se había firmado la convocatoria. Vid. LóPEZ FERREIRO, Fueros municipales, II, p. 195 .

${ }^{10.5}$ López Ferreiro, Historia de la Santa A.M. Iglesia, p. 161.

INeIbidem, pp. 162-163.

${ }^{107}$ Sobre los acontecimientos políticos en Galicia y la determinación de eliminar al arzobispo don Suero ver López FerReiro, Ibídem, pp. 169-171; y Rodríguez González, Pedro I $y$ Galicia, pp. 270-271.

${ }^{1118}$ Crónica de Pedro I, p. 544; y LeIRós, El asesinato del arzobispo don Suero, "Boletín de la Real Academia Gallega", XXXIV (1944), p. 116.
} 
Durante el breve pontificado de don Alonso Sánchez Moscoso (1367), don Fernando de Castro consiguió mantener Galicia para don Pedro, además de muchos pueblos leoneses ${ }^{109}$. Pero esta tranquilidad, un tanto forzada, sólo era el preludio de la tormenta. Su hermano y sucesor en al archidiócesis fue don Rodrigo de Moscoso (1368) quien no dudó en abrazar la causa de Pedro I hasta el extremo de acudir a Sevilla, quizá por invitación del rey, y en febrero de 1369 escribir desde allí a todos los caballeros y escuderos que tenían préstamos de la Iglesia compostelana, ordenándoles que fuesen a dicha ciudad "a serviçio de noso sennor el rey et servyr a nos por las terras e coutos que teedes". Pero todo fue inútil, al ser asesinado el monarca en Montiel un mes más tarde.

Las dificultades que entrañaba la guerra civil fueron la causa, sin duda, de que Pedro I no se parase a ordenar al concejo de Santiago que reconocieran el señorío de don Rodrigo, quien tan fielmente le había servido hasta el final. No obstante, y a pesar de tal fidelidad, Enrique II, según ya anunciamos, no tardó, sin duda por conseguir el favor del arzobispo, en escribir al concejo haciéndole saber que su voluntad era que don Rodrigo tuviera en seguida el señorío de la ciudad y de su término (12 de abril de 1369). El concejo, por su parte, aceptó prestar el homenaje debido al arzobispo, aunque, eso sí, con la aclaración de que éste no debía entenderse para con los titulares futuros. De ahí que, como pudimos comprobar en su día, los enfrentamientos entre el concejo y el arzobispo compostelano seguirían perviviendo muchos años después ${ }^{110}$.

\section{E. Orense}

En Orense, al igual que en Lugo y en Tuy, la lucha contra el señorío eclesiástico fue una constante. En los tres casos, los sucesivos monarcas debieron intervenir en diversas ocasiones, poniendo un singular cuidado en el caso de Tuy, ya que su situación fronteriza y la posibilidad de que alguna de las dos partes enfrentadas buscara el apoyo del monarca portugués lo hacía especialmente peligroso.

Aunque en los primeros tiempos parece ser que se consiguió un cierto equilibrio en Orense entre el señor y el "concilium", los enfrentamien-

\footnotetext{
${ }^{109}$ Crónica de Pedro I, año XVII, cap. XVIII.

"1"ARranz GuZMÁN, Los enfrentamientos, pp. 31-32.
} 
tos entre el obispo y los ciudadanos no tardarían en brotar $^{111}$. Los primeros síntomas graves surgieron durante el gobierno de Fernando III, pero sería a partir del de Alfonso X cuando dichos enfrentamientos mostrarían todo su alcance $^{112}$.

A pesar de que no es éste lugar para relatar cada uno de los disturbios acaecidos a lo largo de los reinados anteriores, sí es necesario subrayar, por un lado, el hecho de que los obispos aurienses mantuvieran siempre el favor de los monarcas y, por otro, que el decisivo apoyo prestado por los soberanos a los titulares del señorío sirvió de poco.

Del malestar general reinante en las ciudades de señorío episcopal de Galicia se hicieron eco, como ya vimos, las cortes vallisoletanas de 1351 . Pero lo que no se mencionó en la asamblea es que, durante todo el siglo $\mathrm{XIV}$, el desorden padecido en algunas diócesis gallegas se debía, en parte, a que los obispos residían poco tiempo en su ciudad, prefïriendo estar esperando en la corte la noticia de haber sido promovidos a otra sede; ni que la cura episcopal, regida en tanto por los arcedianos, se hallaba prácticamente desatendida a causa de la negligencia de sus titulares. Tampoco en estas cortes, quizá por haber sido elegido recientemente, el obispo de Orense don Juan de Cardellac (1351-1365) se había visto todavía en la necesidad de solicitar ayuda a Pedro I para apaciguar a los del concejo. Desgraciadamente, la escasez de documentación nos impide conocer con precisión cómo se desarrollaron los acontecimientos entre el concejo y Cardellac, pero todo hace suponer que el malestar de aquél por la actuación del prelado en el terreno económico no mermó en relación con el de tiempos anteriores.

Alguna noticia más existe sobre su sucesor, don fray Alfonso de Noya. Así, sabemos que tanto él como el cabildo fueron muy favorecidos por Pedro I, hasta que el prelado perdió su amistad ${ }^{113}$. Fray Alfonso de Noya cayó en desgracia por haberse inclinado, al igual que otros prelados, hacia el bando de Enrique de Trastámara, por lo que Pedro I le desterró y

\footnotetext{
"'El "concilium" apareció a finales del siglo XII. En un principio los regidores eran elegidos por el obispo y los "omes buenos" conjuntamente. Vid. GaUTIER DalCHÉ, p. 268.

"'Sobre el desarrollo de los mismos ver C. Sánchez Albornoz, Señoríos y ciudades. Dos diplomas para el estudio de sus recíprocas relaciones, "Anuario de Historia del Derecho Español", (1929), pp. 454-459; y ARRANZ GuZMÁN, Los enfrentamientos, pp. 41-46.

${ }^{113}$ J. Domínguez Fontela, Pedro I el Cruel y la ciudad de Orense, "BCM Orense", XII, pp. 155-56. En 1352 Pedro I confirmó un privilegio de Alfonso XI por el que se declaraba exentos de pagar yantares al deán y cabildo de Orense, not. Duro PEÑa, Catálogo de la Catedral de Orense, doc. 175, p. 58.
} 
encarceló en Almodóvar. Pero lo cierto es que hasta su cambio de partido, el rey siempre se puso de su parte. Prueba de ello es que, tanto en 1361 como en 1367, Pedro I escribió a su merino mayor en Galicia, Suero Yáñez de Parada, y a todos los jueces, concejos, y alcaldes de Orense, para que protegieran a fray Alfonso de cualquier arbitrariedad de la que pudiera ser objeto $^{114}$.

En cualquier caso, a pesar de los problemas acaecidos entre el prelado y Pedro I y de los intentos de emancipación del concejo, al finalizar la guerra civil, siempre enturbiadora de los conflictos particulares, y subir al trono Enrique II, las aguas volvieron a su cauce y, nuevamente, el prelado titular de entonces, don Juan García Manrique, contó desde el primer momento con el apoyo del nuevo monarca. Enrique II no podía olvidar cómo el prelado había seguido su causa. El premio por ello no se hizo esperar: le confirmó sus privilegios y le nombró oidor de su corte, por lo que pasaría la mayor parte del tiempo alejado de su diócesis, siguiendo así la pauta general de los prelados aurienses antes señalada.

\section{F. Lugo}

Lugo, de idéntico modo a otras ciudades de señorío episcopal, presenta una extraordinaria continuidad respecto a la lucha mantenida entre su concejo y el obispo, a pesar de los altibajos ocasionados por sus rebeldías o aceptaciones alternas. Afortunadamente, y en oposición al caso de Orense, existe para Lugo la cantidad suficiente de documentos como para permitirnos seguir con gran precisión los pasos dados en las relaciones concejo-prelado durante el reinado de Pedro I, así como para conocer la actitud de éste en relación con aquéllos ${ }^{115}$.

Desde los tiempos de Fernando III, quien ya se vio obligado a hacer un ordenamiento prohibiendo la creación de hermandades contra la Iglesia y el que los eclesiásticos se mezclaran en cuestiones de legos y viceversa, hasta los de Alfonso XI, los disturbios ocasionados por el descontento del

\footnotetext{
${ }^{114}$ Duro Peña, op. cit., doc. 177, p. 59.

${ }^{115}$ Para la evolución de los acontecimientos en esta ciudad a lo largo del medievo, consúltense: Risco, España Sagrada, vol. XLI; J. VILlaAmIL, Estudio histórico acerca del señorio temporal de los obispos de Lugo en sus relaciones con los municipios en la Edad Media, Madrid, 1897; LóPEZ PELÁEz, El señorio temporal de los obispos de Lugo; Rodríguez GonzÁlez, Pedro I y Galicia, pp. 271-274; y ARRAnz GuZMÁn, Los enfrentamientos, pp. 3441 .
} 
concejo lucense y la fuerza opositora de los sucesivos titulares de la diócesis fueron constantes, aunque salpicadas con paréntesis de leves acuerdos ${ }^{116}$. En efecto, a pesar de las intervenciones regias, la conflictiva situación no había conseguido desvanecerse todavía en tiempos de Alfonso XI. Incluso, podría decirse que las relaciones se habían hecho aún más tensas, aprovechándose los del concejo de la menor edad de Alfonso XI, como lo demuestra el hecho de que tanto el obispo lucense, don fray Juan Cano, como el procurador del concejo, Ferrand Minguéllez, plantearan en cortes, desde diferentes ópticas claro está, las causas del enfrentamiento que ambas partes protagonizaban desde hacía tiempo ${ }^{117}$. Pero de nada sirvió acudir a las cortes, ni tampoco el que el papa Juan XXII excomulgara al municipio siendo ya titular de la diócesis don Rodrigo Ibáñez.

Existía, además, una circunstancia especial que no dejaba de avivar el fuego: el aprovechamiento que algunos oficiales reales hicieron en interés propio, aunque con el teórico propósito de apoyar a los del concejo, ante las ventajosas condiciones que ofrecía la crisis abierta en la ciudad desde hacía varias centurias ${ }^{118}$. En contrapartida, los reyes siempre prestaron su favor y apoyo a los sucesivos prelados; por supuesto, los monarcas obtenían por ello importantes ventajas. Prueba de ello fueron las actuaciones de Alfonso XI, Enrique II y, muy especialmente, de Pedro I.

Quizá, el ejemplo más revelador en cuanto a estrechamiento de lazos se refiere entre los titulares de la diócesis lucense y los monarcas castellanos, sea el protagonizado por Pedro I y su confesor y obispo de Lugo don fray Pedro López de Aguilar. Aunque, en este caso, ha de tenerse en cuenta, de nuevo, la situación de guerra civil, y el hecho de que los ciudadanos lucenses abrazaran también la causa de don Pedro.

Los acontecimientos fueron los siguientes: don Pedro López de Aguilar, quien había sido promovido a la sede en 1349, solicitó al rey que

\footnotetext{
${ }^{116} \mathrm{MUÑOZ}$ Y ROMERO, Colección de fueros municipales y cartas pueblas de los reinos de Castilla, León, Corona de Aragón y Navarra, Madrid, 1847, pp. 132-133. España Sagrada, XLI, p. 348.

${ }^{117}$ Cortes, I, pp. 222, 270, 286, 293 y 296.

${ }^{118}$ Un ejemplo de ello lo tenemos en el hecho de que al partir el obispo don Juan Martínez de viaje hacia Portugal en 1340, el adelantado de Galicia Ruy Pérez de Viezma desposeyó del señorío a quienes lo tenían por la mitra, declarándose libre e independiente. Alfonso XI no tardaría en restituir las cosas a su sitio. Pero el concejo, entonces, se apoyaría en el merino mayor de Galicia, Alvar Rodríguez de la Rocha, quien nuevamente entregaría el señorío de la villa a los ciudadanos. Vid. LóPEZ PELÁEZ, El señorío, pp. 182-183.
} 
llevase a término el litigio existente sobre el señorío temporal de los obispos sobre la ciudad. Pedro I no tardó en darle satisfacción, y el 20 de abril de 1351 comisionaba al bachiller Domingo Beneyto de Salamanca para que instruyera y sentenciara el pleito mantenido entre el prelado y el conce$\mathrm{jo}^{119}$. La sentencia, favorable al obispo, fue dictada el 13 de junio. Unos meses después, el 26 de octubre, el monarca le confirmaba además todos los privilegios, exenciones y mercedes de que gozaba su catedral ${ }^{120}$. Y asimismo, como reacción a los desmanes protagonizados contra los prelados y sus bienes por oficiales reales en tiempos pasados, el rey, con fecha 20 de septiembre de 1352, envió una carta a todos sus funcionarios de Galicia, ordenándoles que respetaran los cotos de la catedral de Lugo así como los derechos de su obispo ${ }^{121}$.

Este respaldo de la corona a fray Pedro tendría inmediata recompensa. En 1355 el rey anunciaba al prelado que Enrique de Trastámara y Fernando de Castro "andaban en deserviçio suyo talando la tierra" y que él había mandado a Alvar Pérez de Castro, a Andrés Sánchez Gutiérrez, a Juan Fernández de Bolaño y a López Pérez de Montao, para que sostuvieran en su diócesis la legalidad. Finalmente, rogaba al obispo que "diese a los dichos posada, favoreciendo en cuanto posible le fuera y que, por el contrario, no admitiese en Lugo ni en sus términos a quien juzgase sospechosos de fidelidad a su real persona" ${ }^{122}$. El prelado defendió la ciudad de sus sitiadores, siguiendo la voluntad de Pedro I, y contribuyó hasta el final, y en la medida de sus posibilidades, para aliviar las necesidades económicas que la guerra ocasionaba a su rey ${ }^{123}$.

\footnotetext{
${ }^{119}$ A.C. Lugo, leg. 5, copia notarial coetánea de la sentencia dictada el 13 de junio de 1351 .

${ }^{120} \mathrm{~L}$. SÁnciez BELDA, Documentos reales de la Edad Media referentes a Galicia. Catálogo de los conservados en la Sección de Clero del Archivo Histórico Nacional, Madrid, 1953, doc. 1.132 , p. 447.

${ }^{121} \mathrm{AHN}$, Códices, 267-B, fol. 216.

${ }^{122}$ A.C. Lugo, lib. 10, no 39. Not. LóPez PelÁEz, El señorío, I, pp. 201-202.

${ }^{123}$ La colaboración económica de fray Pedro López de Aguilar puede apreciarse por el texto de la provisión de Pedro I (Sevilla, 3 de mayo de 1362) ordenando al merino mayor de Galicia, a instancias del prelado lucense, que obligue a los abades de los monasterios de la diócesis a contribuir con don fray Pedro en los servicios extraordinarios solicitados a éste por el rey, A.C. Lugo, leg. 5, copia de 1362, not. LóPEz PELÁEz, El señorío, I, p. 45.
} 


\section{CONCLUSIONES}

Los conflictos analizados a lo largo de estas páginas, protagonizados por los concejos y prelados castellanos, no constituyen el total de los acaecidos durante el reinado de Pedro I; pero sí son lo suficientemente representativos como para permitir poder llegar a una serie de conclusiones en torno a la actitud mantenida por este monarca al respecto.

En las primeras líneas de este estudio nos preguntábamos en qué medida Pedro I siguió la pauta marcada por sus inmediatos antecesores en el trono a la hora de mediar en los diferentes enfrentamientos planteados entre clérigos y laicos. Y, más en concreto, si sus respuestas a cada uno de los litigios presentados estuvieron marcadas por los mismos condicionanates que las de los monarcas anteriores o si, por el contrario, en las relaciones rey-prelados-concejos representaron un alto, una postura aislada, en la trayectoria bajomedieva.

Tras el examen de las quejas y denuncias elevadas indistintamente por clérigos o laicos a Pedro I, podemos llegar a una serie de conclusiones. En primer lugar, y en atención al origen y materia de las mismas, no cabe otra cosa que mencionar su identidad o semejanza con las planteadas en el conjunto de los siglos XIII-XV. Y lo mismo hay que destacar en relación a su localización geográfica, ya que en los conflictos de larga duración en tierras de señorío episcopal este período no representó otra cosa que un momento más, es decir, sin características específicas, en su trayectoria. En segundo lugar, y ya en relación con la actitud gobal mantenida por Pedro I, consideramos que fue similar a la del resto de los monarcas castellanos. Ya que sus arbitrajes, incluso teniendo en cuenta los años de guerra civil, estuvieron condicionados por los mismos factores que marcaron los de aquéllos: las necesidades económicas puntuales del monarca; la situación que pudiera disfrutar un obispo en la corte en función de sus actividades políticas; las relaciones personales más o menos estrechas mantenidas con el rey; el respaldo o no de un concejo a la política regia en momentos bélicos especialmente difíciles; el enfrentamiento abierto por distintos motivos entre el monarca y un prelado; y, por último, el intentar mantener la tan poco nítida demarcación legal entre los ámbitos civil y eclesiástico, presentada con mayor claridad desde Alfonso X e impulsada por su padre Alfonso XI.

Los ejemplos concretos de cómo cada uno de los factores apuntados condicionaron la decisión de Pedro I en los diferentes casos se encuentran 
a lo largo del texto. Sirvan, pues, como mero recordatorio los siguientes: la respuesta dada por el monarca -idéntica a la de sus antecesores- en las cortes vallisoletanas de 1351 ante la queja formulada por los procuradores de las ciudades sobre la actitud de los "excusados" y "familiares de clérigos"; su postura ante la utilización abusiva del arma de la excomunión denunciada en numerosas ocasiones por los laicos; su apoyo al concejo murciano en el asunto de los diezmos de 1368, sin duda relacionado con el paso del obispo de Cartagena al bando trastamarista y su situación de "desobediente al rey"; o su arbitraje favorable a fray Pedro López de Aguilar, titular de la diócesis lucense y confesor de Pedro I.

\section{RÉSUMÉ}

Dans cet article nous analysons l'attitude de Pedro I autour les différents conflits soutenus parmi les "concejos" et les évêques de Castille. Et, en concret, si dans ses décisions il suivit la règle designé par ses prédécesseurs ou, par le contraire, sa procédure fut une posture spécial et isolé.

\section{SUMMARY}

In this paper Pedrot he First's attitude before the different confrontations held in Castille with "concejos" and bishops is analysed. We also, more specifically, deal with the matter if, in his decisions, he followed the lines marked by his predecessors or, on the contrary, his acts were a special and isolated case. 